-Г) Tampere University

TAMPERE ECONOMIC WORKING PAPERS

CAN PAYROLL TAX CUTS HELP FIRMS DURING RECESSIONS?

Youssef Benzarti Jarkko Harju

Working Paper 131

March 2021

FACULTY OF MANAGEMENT AND BUSINESS

FI-33014 TAMPERE UNIVERSITY, FINLAND

ISSN 1458-1191

ISBN 978-952-03-1945-8 (online) 


\title{
Can Payroll Tax Cuts Help Firms During Recessions?*
}

\author{
Youssef Benzarti Jarkko Harju
}

March 25, 2021

\begin{abstract}
This paper estimates the effect of payroll tax cuts on firm-level employment and balance-sheet outcomes during economic downturns. We use two regional payroll tax cuts in Finland as well as the onset of the Great Recession to estimate the effect of the recession on firms treated by the payroll tax cuts compared to a similar control group. When implemented, prior to the Great Recession, we estimate that the payroll tax cuts had limited effects on employment and balance-sheet outcomes of firms located in the treated regions. However, when the recession starts, some of its negative effects were substantially hampered by the previously enacted payroll tax cuts in treated firms. These employment effects are exacerbated for men and low-skilled employees. We also find that sales and profits in treated firms respond differently in treated firms during the recession. We provide some evidence showing that firms that are liquidity constrained are the ones that exhibit the strongest response. This shows that payroll tax cuts can make firms more resilient during downturns, possibly by relaxing liquidity constraints.
\end{abstract}

JEL Classification: H20, H22, H23.

Keywords: Labor costs, place-based policies, great recession, payroll taxes, employment, wages, firms, fiscal multipliers.

\footnotetext{
*Youssef Benzarti, UCSB and NBER (benzarti@ucsb.edu); Jarkko Harju, VATT Institute for Economic Research (jarkko.harju@vatt.fi). We are grateful to Alan Auerbach, Raj Chetty, Cecile Gaubert, Teemu Lyytikäinen, Pat Kline, Emmanuel Saez, Alisa Tazhitdinova and Danny Yagan for helpful suggestions and comments.
} 


\section{Introduction}

How do payroll taxes affect firms during economic downturns? The common wisdom in public finance is that the incidence of payroll taxes is mostly borne by workers, in which case, payroll tax changes should not affect firm-level outcomes. However, recent evidence has questioned this received wisdom, by showing that some, if not all, of the incidence of payroll taxes is borne by firms and can substantially affect firm level activity. ${ }^{1}$ This paper empirically addresses this question by estimating the effect of payroll taxes on firm activity during the Great Recession.

Our empirical strategy relies on using two regional tax cuts in Finland that were enacted several years prior to the Great Recession and were still in place throughout the entire recessionary period. These two waves of payroll tax cuts were enacted in 2003 and 2005 and were repealed in 2012, which allows us to observe the behavior of firms in the treated regions before and after the onset of the Great Recession in 2008 in Finland. ${ }^{2}$ The treated regions are all located in the Northern part of Finland, which is relatively poor compared to the rest of the country. However, not all Northern regions are selected into treatment, which allows us to use the remaining similar Northern regions as a control group. Using a difference-in-difference strategy, we compare firms located in regions treated with the payroll tax cuts to firms in similar control regions where payroll taxes were not changed.

First, we find that the payroll tax cuts, when enacted several years prior to the Great Recession, have very limited effects on earnings and on firm-level outcomes, implying that the savings from the lower payroll tax cuts are likely channeled into firms and likely saved since they do not appear to affect employment, earnings, sales or investment. The clearest effect of the cut in payroll taxes appears at the time of the Great Recession: here we estimate that firms located in the treatment regions exhibit a substantially different behavior than the ones

\footnotetext{
${ }^{1}$ See Saez et al. (2012), Saez et al. (2019), Benzarti et al. (2020) and Benzarti \& Harju (2020).

${ }^{2}$ While the timing of the Great Recession in Finland was similar to that of other European countries (including the fact that it was double dipped), Finland has generally performed worse than many of its peers. More information regarding the effect of the Great Recession on the Finnish economy, including its effect on the Northern regions of Finland, can be found in the following report: Suni \& Vihriälä (2016).
} 
in the control region. In particular, while the Great Recession caused a decrease in earnings in firms located in both control and treatment regions, these decreases are substantially smaller in the treated regions. And these effects seem to be particularly acute for low-skilled workers. Overall, the net of payroll tax wage bill is relatively higher for firms in the treated regions, consistent with them paying their employees relatively more. While the employment effects are somewhat noisier, we also find that treated firms employ relatively more workers, which could be due to either more hiring or fewer separations. In addition, treated firms also invest relatively more and realize more sales than control firms during the Great Recession. Importantly, some of these effects are long lived and tend to persist even after the payroll tax cuts are repealed in 2012. This is particularly true for the employment effects. One candidate explanation for the finding that payroll taxes help firms during recessions is that they relax liquidity constraints. We find evidence consistent with this interpretation: treated firms that have widely available liquid assets have a muted response to the Great Recession, whereas those firms that face liquidity constraints exhibit the strongest response. This suggests that payroll taxes help firms by relaxing their financial constraints.

Our main identification assumption is that firms in the treatment regions would have behaved similarly to firms in the control region had there been no change in payroll taxes. A common test of this assumption is to ensure that trends in the control and treatment groups are parallel prior to the change in payroll taxes. Our graphical evidence is consistent with this identification assumption. We also show evidence that the control and treatment regions are very similar along many observable characteristics. This is likely due to the fact that regions were selected into treatment not because of their economic conditions but rather because of political considerations: the payroll tax cuts were targeted at Northern regions only, which are typically poorer than the rest of Finland, but among these regions, it did not affect the poorest ones. While all the treatment regions are relatively poor compared to the rest of Finland, they are not the poorest regions in the area.

Our main contribution is to shed light on the effects of payroll taxes during recessions, 
which is a question that had not been addressed by previous literatures. In doing so, we contribute to three main strands of literatures. First, we contribute to the tax incidence literature and, in particular, to the few papers that address the question of who bears the incidence of payroll taxes. Our main contribution to this literature is to assess whether the incidence of payroll taxes depends on the business cycle. This literature has mostly focused on estimating the incidence of payroll taxes without paying much attention to business cycles. While older papers have mostly estimated that workers bear the incidence of payroll taxes (Gruber (1997)), recent results (Saez et al. (2012), Saez et al. (2019) and Benzarti \& Harju (2020)) show that firms are likely to bear a substantial burden of the incidence of payroll taxes. Relatedly, Bozio et al. (2019) show that this burden crucially depends on whether payroll taxes are linked to the benefits they fund. Notably, Korkeamäki \& Uusitalo (2009) use the same variation from the first wave of the experiment as we do to study short-term responses and find no clear wage or employment responses. ${ }^{3}$ Finally, Huttunen et al. (2013) finds no employment or wage responses to a very targeted payroll tax cut for the employers of older and low-wage workers in Finland.

Second, we contribute to a public finance literature that assesses whether government intervention should vary during the business cycle. While we do not address this question directly - we do not derive optimal payroll tax rates over the business cycle - we provide evidence that the effect of payroll taxes varies over the business cycle, which can help inform future research on this question. In public finance, this literature has mostly focused on the optimal provision of unemployment insurance (see Landais et al. (2018a) and Landais et al. (2018b)) and on public expenditure (Michaillat \& Saez (2019)).

Relatedly, our results have implications for the effectiveness of stimulus programs. Our paper is closely related to Ku et al. (2020), who show that place-based payroll tax cuts are partially shifted to employees and have large employment effects. We complement their

\footnotetext{
${ }^{3}$ Korkeamäki (2012) also studies the longer term effects of the experiments, and uses the variation from the second wave of the experiment (in his $\mathrm{PhD}$ dissertation) but does not consider the effects of the payroll tax cut during the Great Recession.
} 
analysis by focusing on the effect of place-based payroll tax cuts during periods of severe economic downturns. While there are several papers showing that Value-Added Tax cuts are ineffective at stimulating firm activity as they are mostly passed through to profits (see, e.g. Benzarti \& Carloni (2019); Kosonen (2015); Benzarti et al. (Forthcoming); Harju et al. (2018)), few papers have considered the stimulus effects of payroll taxes. Our findings suggest that they can have long-run effects on firm activity by increasing production, output and profits even after the cuts are repealed. They also lead to higher wages, which can also stimulate demand.

Finally, our results are also closely related to papers estimating the effect of place-based policies (reviewed for example in Kline \& Moretti (2014) and Neumark \& Simpson (2015)). In our empirical setting the payroll tax cuts were targeted to high unemployment areas and aimed at increasing employment. Our empirical findings support the view that reducing payroll tax rates in areas suffering from poor economic conditions can increase economic activity, especially during downturns.

\section{Institutions and empirical setting}

\subsection{The Finnish Payroll Tax System}

The payroll tax system in Finland is similar to that of other countries in that it funds social insurance programs including old age insurance, unemployment insurance, health insurance and other smaller programs. Both employers and employees are statutorily liable for paying a given portion of payroll taxes with a higher share for employers. The tax rate schedule is a function of several firm and employee characteristics including the age of the worker, the size of the firm, the capital intensity of the firm and other observable characteristics. The average employer-level payroll tax rate varies over time and by firm characteristics and has been higher than $20 \%$ for the past two decades. Appendix Table 8 shows a detailed description of the percentages by years by different firm categories. 
The Finnish Payroll Tax Experiments. In this paper we use two regional and temporary payroll tax rate cut experiments as a source of exogenous variation. Talks about experimenting with payroll taxes on a set of Finnish regions started in December 2001. A proposal of temporarily repealing employer contributions to the National Pension Insurance and the National Health Insurance was brought to a vote in the Parliament in September 2002. The first wave of cuts was approved in December 2002. The payroll tax was repealed in January 2003, resulting in a cut of 3 to 6 percentage points of the total payroll tax rate, depending on firm-level characteristics (see Appendix Table 8). The goal of this repeal was to experiment with lowering payroll taxes in a group of Finnish municipalities in order to assess the effects of payroll taxes on employment. With this goal in mind, twenty municipalities were first chosen among a set of relatively high unemployment municipalities. Importantly, while only poor municipalities were considered, the twenty municipalities that made it into the treatment group were not selected solely based on economic conditions. Instead, the final selection of these treated municipalities was the result of intense political negotiations. ${ }^{4}$ As such, some of the highest unemployment areas were not part of the experiment and there were also areas with equally high unemployment rates that were excluded from the treatment group. The experiment resulted in the removal of the national health and pension insurances portion of contributions for firms located in the twenty treated municipalities. ${ }^{5}$ Importantly, current and future benefits were not affected by the cut in payroll taxes which applied to all employees in a given firm, as long as it was located in one of the treated regions. All private employers registered for operation in the treated municipalities were eligible for the payroll tax cut.

The law was passed with the European Union de minimis regulations which regulates firm

\footnotetext{
${ }^{4}$ Korkeamäki (2012) and Korkeamäki \& Uusitalo (2009) provide a detailed narrative of the first wave of the experiment, which we summarize here.

${ }^{5}$ The target region consisted the following twenty municipalities mostly from the Lapland of Finland: Enonteki, Hailuoto, Houtskari, Inari, Ini, Kemijrvi, Kittil, Kolari, Korppoo, Muonio, Nauvo, Pelkosenniemi, Pello, Posio, Salla, Savukoski, Sodankyl, Utsjoki, Velkua and Ylitornio. However, in this paper we do not include firms located in six municipalities on the islands of the west coast of Finland due to their small size and remote location. These are: Hailuoto, Houtskari, Ini, Korppoo, Nauvo and Velkua.
} 
subsidies in EU Member States. This meant that the agriculture, fishing and transportation sectors were excluded from the experiment.

The second wave of the experiment took place in January 2005, which included additional municipalities, mostly from the Kainuu region of Finland. ${ }^{6}$ Firms that were located in these municipalities were subject to the same payroll tax cuts as the ones from the first wave of the experiment. There was a third wave of experimentation in 2007, which started in January 2007. This wave added six of the most eastern municipalities. However, we do not analyze this last wave of expansion, as these areas have very few firms and its onset was too close to that of the Great Recession (these regions are excluded from the analysis).

All waves of the experiment ended in December 2011. ${ }^{7}$ Therefore, the first wave lasted nine years and the second one six with substantial overlap with the Great Recession, which started mid-2008 in Finland. Starting from January 2012, the firm-level payroll tax rates were increased in the treatment municipalities so as to match those of the rest of the country. Appendix Table 8 shows the employers' contribution rates over time. ${ }^{8}$

Minimum Wages And Wage Setting. Finland does not have a government mandated minimum wage. Instead, wage bargaining occurs at the national level between employer and employee representatives, setting a wage floor that depends on several characteristics including employee tenure, industry of employment and other observable characteristics. When the central agreement is reached, the negotiations continue at the sector-level, usually by each industry. These negotiations set a representative wage level increase in these sectors

\footnotetext{
${ }^{6}$ These municipalities were: Kajaani, Kuhmo, Hyrynsalmi, Paltamo, Puolanka, Ristijrvi, Sotkamo, Suomussalmi, Vaala and Vuolijoki.

${ }^{7}$ The tax cuts were originally set to expire by the end of 2006 . However, it was then decided to extend them to the end of 2009. In December of 2009, they were extended one more time to December 2011. While the temporary nature of the experiments could, in principle, affect the incidence results, it is very hard to know what these effects could be. With the caveat that it is in a different setting and for a different type of tax, Benzarti et al. (Forthcoming), show that firms respond similarly to VAT changes that are perceived to be temporary or permanent.

${ }^{8}$ Note that there was a 0.8 percentage point payroll tax cut that affected all firms in Finland in April 2009 and a larger cut starting in January 2010 as the firm size categories for national health and pension insurances were removed and harmonized to the lowest payroll tax rate.
} 
but also a minimum wage for each job task. These wage floors are likely to affect the passthrough of payroll taxes in a similar way national minimum wages would in other countries. ${ }^{9}$

Importantly, these wages apply to all workers, not only to the employees that belong to labor unions. Although collective bargaining applies to more than $90 \%$ of workers, wages can vary across firms and across employees within firms. Firms, of course, can increase or decrease wages as long as the minimum wage rules are not violated. Therefore, wages can vary considerably across firms in the same job tasks.

\subsection{Data}

We use a panel dataset of firm-level tax returns, covering the universe of firms in Finland. The data are annual and contain information on every line of profits and losses at the firm level, thus allowing us to observe, for example, sales, fixed and variable costs separately, as well as number of employees (measured in full-time equivalent), total wage sums and investments. Importantly, the dataset also includes the exact address of each firm, which is essential for assigning firms to treatment and control groups. The dataset covers the years 1999 to 2015, but some variables are missing from 1999 to 2002. However, our main outcomes of interest (payroll tax bill, number of employees, employee-level earnings, total labor costs, sales and profits) are all available from 1999 onwards.

The second dataset used in the analysis includes employer-reported wage information of all employees. These data, which link employees to firms, cover sole proprietors starting from 2006 onwards. For this reason, we exclude them from the analysis. Note that, although there are many sole proprietors in the data, they are all very small and employ very few workers (0.5 on average in 2002) and therefore are mostly unaffected by the payroll tax changes we analyze. These individual-level data contain detailed information on earnings, socioeconomic status and other important employee-level characteristics such as demographic

\footnotetext{
${ }^{9}$ It is hard to know how many workers earn the minimum wage, because there are many wage floors. However, evidence from the retail industry (Böckerman \& Uusitalo (2009)) suggests that this proportion might be 10 to $15 \%$.
} 
information on the employee: age, gender, education, tenure of job contracts, etc. Overall, using unique identifiers, we are able to link the firm-level data to the employee-level data for $97 \%$ of corporations and partnerships.

\subsection{Estimation Strategy}

We estimate the effects of the two payroll tax reforms using a difference-in-differences estimation strategy at the firm level. Formally, we estimate the following equation:

$$
\begin{aligned}
Y_{i, t}= & \alpha_{0}+\alpha_{1} A_{i}+\alpha_{2}\left(A_{i} * \text { Recession }_{t}\right)+\alpha_{3}\left(A_{i} * \operatorname{Exp}_{1 t}\right) \\
& +\alpha_{4}\left(A_{i} * \operatorname{Exp}_{2 t}\right)+\gamma_{i}+\mu_{t}+\epsilon_{i, t}
\end{aligned}
$$

where $Y_{i, t}$ represents the variable of interest in logs, i.e., payroll taxes paid, labor costs net of the employer portion of payroll taxes, employee-level earnings, number of employees, sales, profits, etc. $A_{i}$ is equal to one if firm $i$ is located in one of the treated municipalities and zero if it is in one of the control municipalities, which we define below. $A_{i} *$ Recession $_{t}$ is the interaction term for firms in treatment areas in the post recession period, years 2009 to 2015. $\operatorname{Exp}_{1 t}$ is equal to one for the first wave of the payroll tax experiments (2003 to 2011) and the second wave (2005 to 2011), and is zero otherwise. Exp $p_{2 t}$ is equal to one for the post-experiment period (2012 to 2015), and zero otherwise. We also include industry-year fixed effects to account for sectoral dynamics over time. Firms are weighted by firm-level pre-reform labor cost levels in all specifications, using the average firm-level labor costs from 1999 to 2002. Standard errors are clustered at the municipality level, which is the source of the variation we are exploiting in this paper. We estimate this equation using an unbalanced panel of active firms. Importantly, there is no evidence of entry/exit around

the two reforms or at the time of the Great Recession, as can be seen in Appendix Table 10 and Appendix Figure 13, thus mitigating concerns over compositional effects driving the 
results. ${ }^{10}$ Relatedly, we also find limited firm mobility in and out of the treatment regions, as can be seen in Appendix Figure 14 and Appendix Table 11.

The main coefficients of interest are $\alpha_{2}, \alpha_{3}$ and $\alpha_{4} ; \alpha_{2}$ identifies the effect of the payroll tax rate cuts on the post-recession years (2009 to 2015), $\alpha_{3}$ corresponds to the effect of the tax cuts on firms at the time of the cuts (for both waves) and $\alpha_{4}$ identifies the effect of payroll tax cuts post-Great Recession. In equation $1, \mu_{t}$ represents year fixed effects, $\gamma_{i}$ corresponds to firm fixed effects and $\epsilon_{i, t}$ is the error term.

The main identification assumption is that, absent payroll tax changes, there would have been no change in outcomes of the treated group relative to the control group. To validate this assumption, we inspect the pre-treatment trends of the outcomes of interest in Section 3.1 across treatment and control groups and show that pre-trends are parallel.

The control group is constructed so as to include all neighboring municipalities that share a border with the targeted municipalities, but exclude the four largest cities (Rovaniemi, Oulu, Kuopio and Joensuu) close to the treatment municipalities, as these were explicitly excluded from the treatment group when the experiment was being designed by the Finnish Government. ${ }^{11}$

Figure 1 shows the different treatment regions and the control municipalities. The control and treatment groups appear to be reasonably similar, as shown in Figure 2. This Figure plots average municipality-level outcomes of four main economic measures over time separately for the whole country, as well as for the control and treatment regions. Figure 2 shows that both treatment regions and control regions have, on average, lower employment rates and tax revenue per capita relative to all municipalities in Finland as well as higher unemployment rates and higher government subsidies. However, the treatment municipalities are very comparable to the control municipalities, consistent with the fact that assignment to

\footnotetext{
${ }^{10}$ Note that this lack of entry and exit responses is consistent with the findings of Benzarti et al. (2020) and Benzarti et al. (Forthcoming).

${ }^{11}$ The municipalities in the control area are: Ii, Iisalmi, Kaavi, Keminmaa, Kiuruvesi, Kontiolahti, Kuusamo, Krsmki, Lapinlahti, Liminka, Liperi, Maaninka, Muhos, Pielavesi, Polvijrvi, Pudasjrvi, Pyhjrvi, Pyhnt, Ranua, Siikalatva, Simo, Sonkajrvi, Taivalkoski, Tervola, Tohmajrvi, Tornio, Tuusniemi, Tyrnv, Utajrvi and Vierem.
} 
treatment was not solely based on economic conditions. Municipalities in the control group have slightly higher employment rates and lower unemployment rates compared to the treatment group, but these level differences are not large. More importantly, the pre-experiment trends across groups are very similar. There are no noticeable differences in levels or trends for tax revenue (exclusive of payroll taxes) and government subsidies across the treatment and control municipalities. It is also worth emphasizing that in many control municipalities, employment rates are lower and unemployment rates higher relative to the treatment municipalities, which further suggests that economic conditions were not the main or only criterion of assignment to treatment. In addition, Appendix Table 12 shows a breakdown of our sample by industry and treatment status. With the exception of hotels and restaurants, all industries appear to be reasonably equally represented in the sample across the control and two treatment areas.

Table 1 shows the firm-level descriptive statistics by treatment and control regions in 2002. Employment, average wages, sales (turnover) and profits are similar across the control group and the two treatment groups.

\section{Results}

\subsection{Graphical Evidence}

In this section, we plot our main outcomes of interest separately for the treatment and control groups. We do this for two reasons: (1) to validate the parallel trend assumption needed for our difference-in-differences estimation strategy and (2) to visually assess the response of our main outcomes to the payroll tax reforms and to the Great Recession. Each figure plots the coefficients from a fixed effect regression of the outcome of interest, namely, the amount of payroll taxes, payroll costs net of taxes, number of employees and labor input in months at the firm level on year dummies weighted by pre-reform firm-level annual labor costs. For

all figures we also remove the level differences between groups by indexing all groups to zero 
in 2002, a year before the first experiment, and thus the figures show the changes in levels relative to this year. ${ }^{12}$

Payroll Taxes Paid by Firms. The upper-left panel of Figure 3 plots average firm-level payroll taxes from 1999 to 2015 relative to year 2002. Both treatment and control groups exhibit parallel trends prior to the reform. We observe a decrease in average payroll taxes paid in the first year after the treatment starts for both treatment groups, in 2003 for the first treatment group and 2005 in the second one. As the payroll tax rates are reverted back to the same level to that of the control municipalities (and the rest of the country), in 2012, the response of the treatment group relative to the control group appears to be larger than the response to the payroll tax cut. This asymmetry could be consistent with an increase in number of employees or an asymmetric response of wages to payroll tax cuts, which we investigate next.

Firm-level labor costs and employment. Payroll tax cuts increase the incentive to hire and retain employees. To assess the effect of this incentive, we first plot firm-level labor costs net of the employer portion of payroll taxes over time in the upper-right panel of Figure 3. Wage costs, which we call total posted wages in the rest of the paper, includes all costs of employees (net of the employer portion of payroll taxes), a variable that is directly available in our data. Both treatment and control groups follow parallel trends from 1999 to 2002, validating our empirical approach. In the first treatment group there is a clear increase in labor costs right after the reform in 2003 compared to the control group. The pattern is a bit different for the second treatment group. There is a small increase already in 2005 in the second treatment area but it seems to take two years after the start of the treatment for there to be a clear increase in labor costs.

In principle, the payroll tax decrease in the treatment regions could also affect the survival rate of firms, increase entry and movement of existing firms towards the treated municipali-

\footnotetext{
${ }^{12}$ Appendix Figures 4-11 show the DD estimates over time for pooled treatments for each outcome.
} 
ties. If these effects are present and large, they could also create a challenge for our empirical setting. Appendix Figures 13 and 14 show the number of firms entering into, exiting from and moving into the treatment regions. Although there seems to be large annual variation for these outcomes, the figures suggest no systematic differences during or after the experiment period which suggests that payroll tax cuts do not affect firm entry, exit or location choices, and also that our empirical approach is not threatened by these types of responses.

In order to study the changes in employment over time, we plot the number of employees and labor input in months. Number of employees represents the number of job contracts a firm has during a given year and labor input in months represents the number of months employees have worked at a given firm within a year. Therefore, both of these measures describe the amount of labor input used in firms. The lower-left panel of Figure 3 shows that the pre-experiment trends in the number of employees are reasonably parallel, although the pre-trend for the second treatment group is somewhat different. The number of employees increases gradually after the start of the treatment periods for both treatment groups compared to the control group. The difference with the control group clearly increases after the start of the Great Recession from 2008 onward. Therefore, the level of employment is clearly increasing in the post-recession period in the treatment compared to the control group. The lower-right panel of Figure 3 shows similar effects for labor inputs in months.

Figure 6 shows the effect of the payroll tax cuts on other firm-level outcomes, namely sales, investments and profits. Sales follow parallel trends prior to the reform and do not appear to be responding to the payroll tax cut. There is a divergence between the control and the two treatment groups at the onset of the Great Recession. This differential response persists over time and suggests that lower payroll taxes may have helped treated firms cope better with the effects of the financial crisis. The lower-left panel of Figure 6 shows a similar pattern for investment: they follow parallel trends during the pre-treatment period and there is no change in investments during the treatment period or after the Great Recession. The lower-right panel of Figure 6 shows the response of profits: pre-reform trends are parallel and 
profits increase as payroll taxes are cut and remain at higher levels for the entire experiment period, and even once the payroll tax cuts are repealed. This suggests that temporary payroll tax cuts can have long lasting effects even when the payroll tax rates are brought back to their original levels.

Employee-level earning responses. Figure 7, plots average employee-level earnings at the firm level in the treatment and control groups over time. There is no change in average employee-level earnings following the payroll tax rate cuts in the treatment groups relative to the control group. This suggests that firms do not reduce employee wages after the payroll tax cuts, and thus the incidence of payroll taxes appears to be borne by firms. However, starting from 2008 onward, average earnings are higher in both treatment groups compared to the control group. Surprisingly, the gap between treatment and control groups remains even after the payroll tax rates are reverted back to the same level after 2011.

Figure 9 shows the employee-level earning responses by gender, education and by types of job tasks. The figure shows no changes in earnings among any of the groups in the two treatment regions right after the payroll tax cut. However, starting in 2009, the earnings diverge in both treatment groups relative to the control group. This effect is most prevalent among men, low educated (non-college) workers and employees working in lower-level and manual tasks.

Employee-level employment responses. Figure 10 shows employment responses using the same categorization of employees by their characteristics we used for employee-level earnings. As is visible from these figures, the pre-payroll tax cut trends are far from perfect complicating any reasonable inference. Therefore, these results should be interpreted with caution. However, it appears that the positive employment responses are relatively larger for men, non-college educated, upper- and lower-level workers.

In order to quantify all of the effects mentioned in this section and their associated standard errors we show regression estimates using a difference-in-differences framework. 


\subsection{Regression results}

Average responses of firm-level labor outcomes. Table 2 shows the results of estimating equation (1) on firm-level outcomes. Column (1) shows that the amount of payroll taxes decreases by $30 \%$ on average in both treatment groups right after the experiment starts relative to the control group. This confirms that firms in the treated municipalities indeed experienced a cut in their payroll tax burden.

Column (2) shows that the experiments increased firm-level labor costs net of payroll taxes but only after the recession. This is consistent with the persistent effect on payroll taxes paid shown in Column (1). The estimates for the effect of the payroll tax cut experiments are all small and not statistically significant. Column (3) shows that the number of workers in treated firms increased by $5 \%$ during the post-recession period. Similarly, estimates for the effect of the payroll tax cut experiments are small and statistically insignificant. Column (4) also shows that the results are very similar using the number of total working months of all workers within a firm during a year as an alternative measure for labor input.

As a robustness check, we also re-estimate our baseline results (the ones presented in Table 2) by re-weighting the comparison group so that it has the same initial sectoral composition as the treatment group. We follow the strategy used in e.g. Yagan (2015) and Zwick \& Mahon (2017). In particular, we first assign each observation to one of the seventeen industry categories that are shown in Appendix Figure 12. Next, we divide each industry category into five size groups based on annual revenue. This leaves us with eighty-five industry-size bins for the control and treatment groups for each year. Finally, we calculate the weight factor by weighting the sum of revenues in each bin to match firms in the pre-reform treatment group in 2000-2002. Table 3 shows the results of this approach: all point estimates are quantitatively and statistically similar to those presented in Table 2.

Effect on firm-level production. The estimated firm-level production responses at the time of the Great Recession are larger than those triggered by the changes in payroll taxes 
but are very noisily estimated, making any statements about firm-level production at best suggestive, as can be seen in Table 4. The only effect we can detect with a reasonable degree of certainty is that input usage is higher in the treated regions even after the payroll tax cut is repealed. This is also consistent with an increase in total labor costs as we discuss below when addressing cumulative effects.

Effect on employee-level earnings. Table 5 shows the average employee-level earning responses. Column (1) shows that the average earnings level is higher in the treated firms after the recession compared to firms in the control region. These effects are mostly driven by low-skilled workers holding non-managerial and manual jobs. This effect is not persistent and disappears once the payroll tax cut is repealed as can be seen from the cumulative effect estimates.

Effects on employment. Table 6 shows the employment responses using a classification of workers similar to that used in Table 5. The estimates in Table 6 suggest that the increase in employment is driven by female and low-educated employees, and employees in non-manual jobs. Note, however, that few of the employment estimates are very precise.

Cumulative effects We systematically report the cumulative effects which add up the effects of the two payroll tax changes and the Great Recession. Overall, the cumulative effects appear large and significant for total labor costs net of payroll taxes and for inputs use. This is consistent with firms producing more, although we do not detect a substantial change in sales. All of the remaining cumulative effects are of small magnitude and statistically indistinguishable from zero, suggesting that the long-term consequences of the temporary payroll tax cuts for these other outcomes are negligible.

Liquidity constraints What could explain these results? One possible mechanism for payroll taxes helping firms during the Great Recession is that they provide a financial buffer 
that can be particularly helpful for firms facing financial constraints. We test this assumption in the following way: (1) we break down our sample of firms into five quintiles of financial liquidity, which we define as the ratio of liquid assets to total assets and then (2) we estimate equation (1) on employment outcomes separately on these five quintiles. The results are reported in Table 7, which shows that employment responses are really concentrated among firms that are the most liquidity constrained (the fifth quintile) and thus is consistent with the hypothesis that payroll tax cuts help firms in recessions by relaxing their liquidity constraints.

\section{Conclusion}

This paper estimates the effect of payroll taxes on firm activity during the Great Recession by exploiting two regional payroll tax cuts that were enacted several years prior to the start of the economic downturn. By comparing firms located in regions with lower payroll tax rates to firms in similar regions unaffected by the payroll tax cuts, our results show that temporary payroll tax cuts have very limited effects on individual-level earnings and firmlevel outcomes right after their implementation. However, while the Great Recession led to a decrease in earnings in firms located in both control and treatment regions, these decreases are substantially smaller in the regions with lower payroll tax rates.

Therefore, our findings suggest that payroll tax cuts could be a way to stimulate firm activity during downturns, and could be more effective than VAT rate cuts, for example, which have been found to be relatively ineffective (see, e.g. Benzarti \& Carloni (2019); Kosonen (2015); Benzarti et al. (Forthcoming); Harju et al. (2018)).

\section{References}

Benzarti, Youssef \& Dorian Carloni. 2019. Who Really Benefits From Consumption Tax Cuts? Evidence From a Large VAT Cut in France. American Economic Journal: Economic Policy . 
Benzarti, Youssef, Dorian Carloni, Jarkko Harju \& Tuomas Kosonen. Forthcoming. What Goes Up May Not Come Down: Asymmetric Incidence of Value Added Taxes. Journal of Political Economy .

Benzarti, Youssef \& Jarkko Harju. 2020. Using payroll tax variation to unpack the black box of firm-level production. NBER Working Paper No. 26640 .

Benzarti, Youssef, Jarkko Harju \& Tuomas Matikka. 2020. Does Mandating Social Insurance Affect Entrepreneurial Activity? American Economic Review: Insights .

Böckerman, Petri \& Roope Uusitalo. 2009. Minimum wages and youth employment: Evidence from the finnish retail trade sector. British Journal of Industrial Relations 47(2). $388-405$.

Bozio, Antoine, Thomas Breda \& Julien Grenet. 2019. Does tax-benefit linkage matter for the incidence of social security contributions? Working Paper .

Gruber, Jonathan. 1997. The incidence of payroll taxation: Evidence from chile. Journal of Labor Economics 15(3).

Harju, Jarkko, Tuomas Kosonen \& Oskar Nordstrm-Skans. 2018. Firm types, price-setting strategies, and consumption-tax incidence. IFAU Working Paper 2018:4 .

Huttunen, Kristiina, JukkaPirttilä \& RoopeUusitalo. 2013. The employment effects of lowwage subsidies. Journal of Public Economics 97. 49-60. doi:https://doi.org/10.1016/j. jpubeco.2012.09.007.

Kline, Patrick \& Enrico Moretti. 2014. People, places, and public policy: Some simple welfare economics of local economic development programs. Annual Review of Economics 6. 62962. doi:10.1146/annurev-economics-080213-041024.

Korkeamäki, Ossi. 2012. Essays on labour demand and wage formation: VATT Institute for Economic Research, Publications 60 dissertation.

Korkeamäki, Ossi \& Roope Uusitalo. 2009. Employment and wage effects of payroll tax cut - evidence from a regional experiment. International Tax and Public Finance 16. 753772. Kosonen, Tuomas. 2015. More and cheaper haircuts after vat cut? on the efficiency and 
incidence of service sector consumption taxes. Journal of Public Economics 131(C). 87100.

Ku, Hyejin, Uta Schönberg \& Ragnhild C Schreiner. 2020. Do place-based tax incentives create jobs? Journal of Public Economics 104105.

Landais, Camille, Pascal Michaillat \& Emmanuel Saez. 2018a. A macroeconomic approach to optimal unemployment insurance: Applications. American Economic Journal: Economic Policy 10(2). 182-216.

Landais, Camille, Pascal Michaillat \& Emmanuel Saez. 2018b. A macroeconomic approach to optimal unemployment insurance: Theory. American Economic Journal: Economic Policy 10(2). 152-81.

Michaillat, Pascal \& Emmanuel Saez. 2019. Optimal public expenditure with inefficient unemployment. The Review of Economic Studies 86(3). 1301-1331.

Neumark, David \& Helen Simpson. 2015. Place-based policies. Handbook of Regional and Urban Economics 5B. doi:http://dx.doi.org/10.1016/B978-0-444-59531-7.00018-1.

Saez, Emmanuel, Manos Matsaganis \& Panos Tsakloglou. 2012. Earnings determination and taxes: evidence from a cohort-based payroll tax reform in greece. The Quarterly Journal of Economics 127(1). 493-533.

Saez, Emmanuel, Benjamin Schoefer \& David Seim. 2019. Payroll taxes, firm behavior, and rent sharing: Evidence from a young workers' tax cut in sweden. American Economic Review 109(5). 1717-63.

Suni, Paavo \& Vesa Vihriälä. 2016. Finland and its northern peers in the great recession. Tech. rep. ETLA Report.

Yagan, Danny. 2015. Capital tax reform and the real economy: The effects of the 2003 dividend tax cut. American Economic Review 105(12). 3531-63.

Zwick, Eric \& James Mahon. 2017. Tax policy and heterogeneous investment behavior. American Economic Review 107(1). 217-48. 
Figure 1: Municipalities in the treatment and control groups

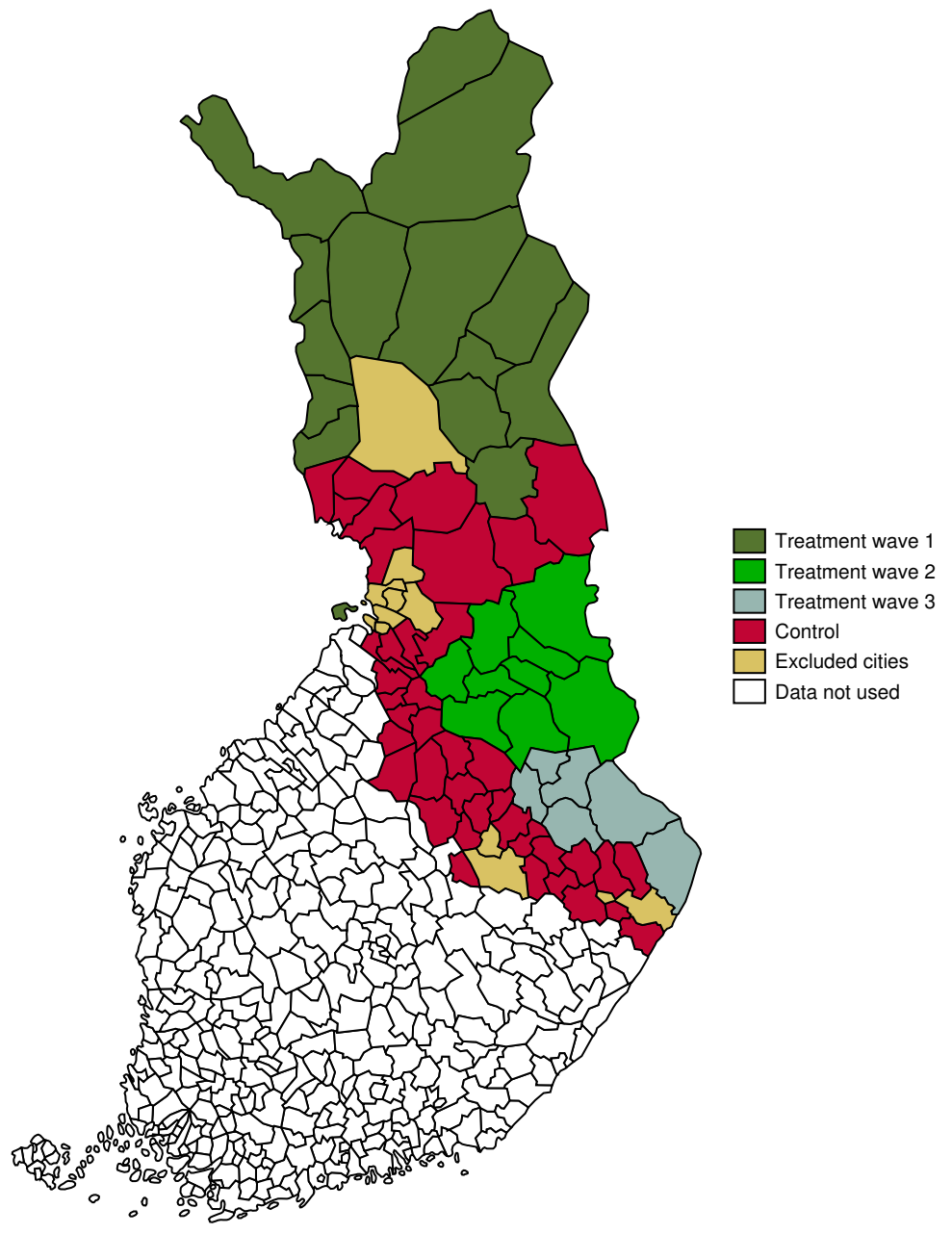

Note: This figure shows the map of Finland with the corresponding municipality borders in 2002. Colors on the map show the municipalities where the payroll tax cuts were enacted, the control municipalities, the excluded cities and the municipalities we do not include in our empirical analysis. 
Figure 2: Municipality-level comparisons in the treatment and control regions and all of Finland
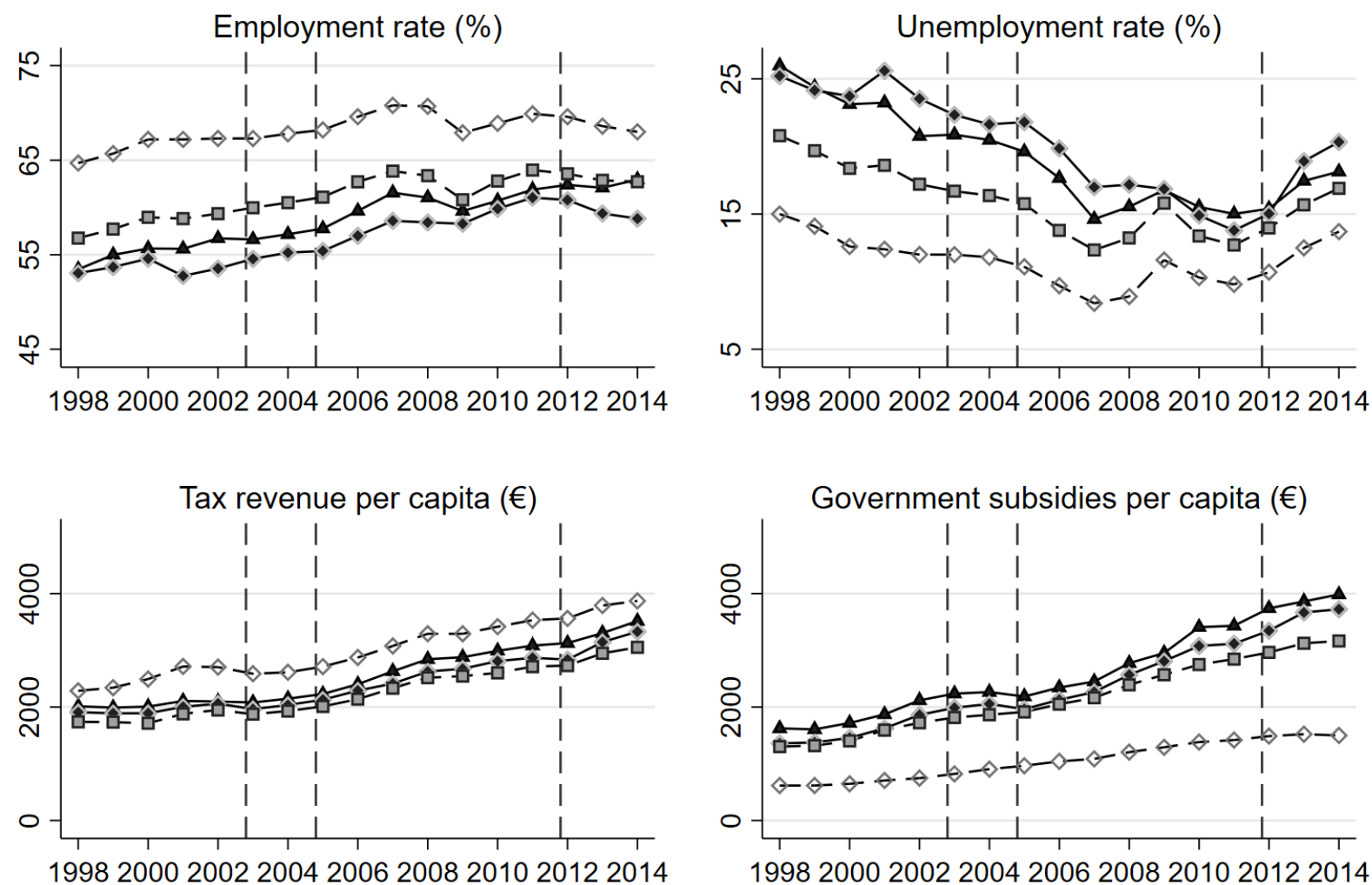

\section{$\Delta$ Treatment area $1 \triangleleft$ Treatment area 2 Control area $\diamond$ Whole country}

Note: These figures plot the average municipality-level outcomes of four main economic indicators (employment rate, unemployment rate, tax revenue per capita and government subsidies per capita) over time for the whole country, the control and the treatment regions used in the empirical analysis. The first and second dashed vertical lines correspond to the start of the first and second waves of the payroll tax experiments. The third dashed vertical line corresponds to the end of both waves of the experiment. 
Figure 3: Firm-level payroll taxes, total posted wages, number of workers and labor input

(a) Payroll Taxes

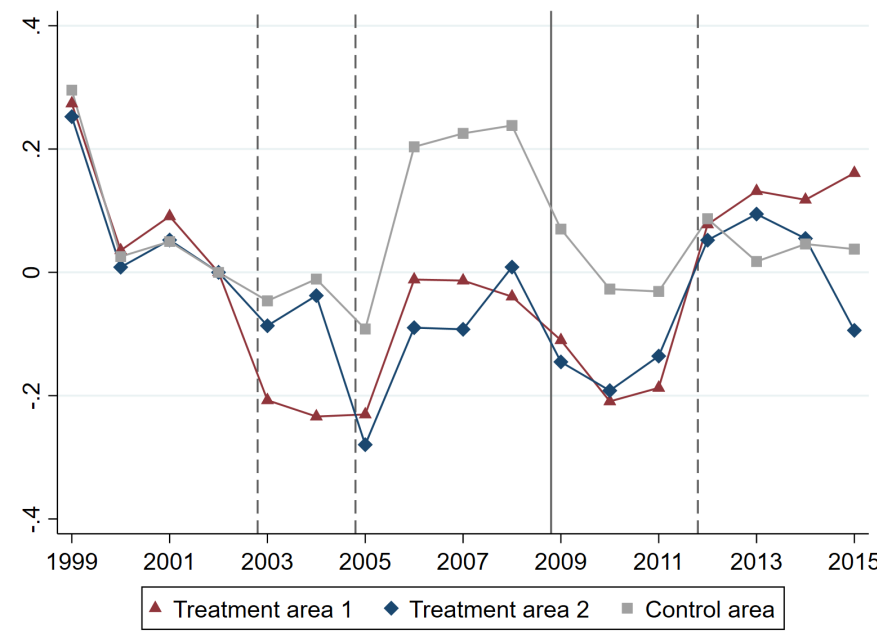

(c) Number of Employees (Full Time Equivalent)

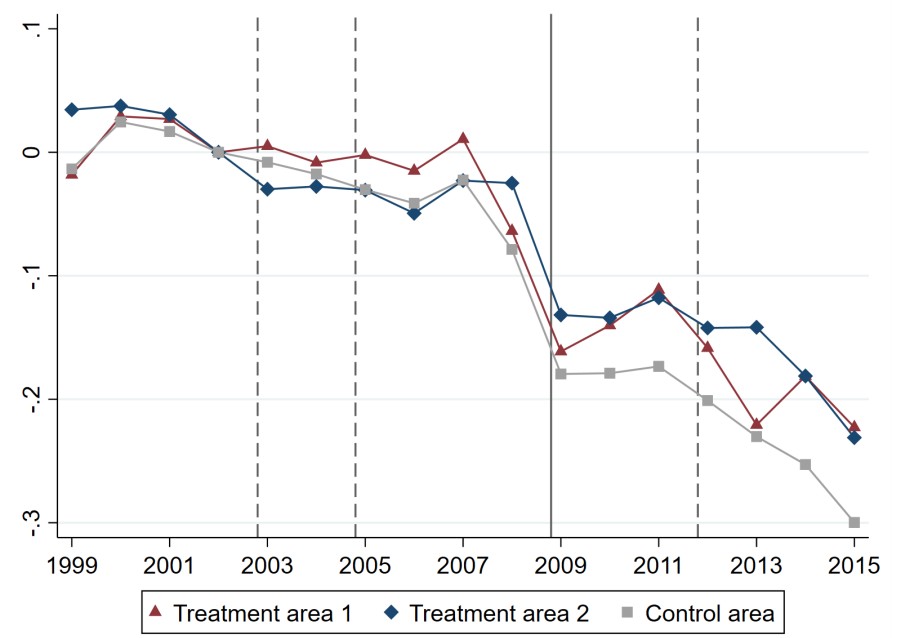

(b) Total Posted Wages

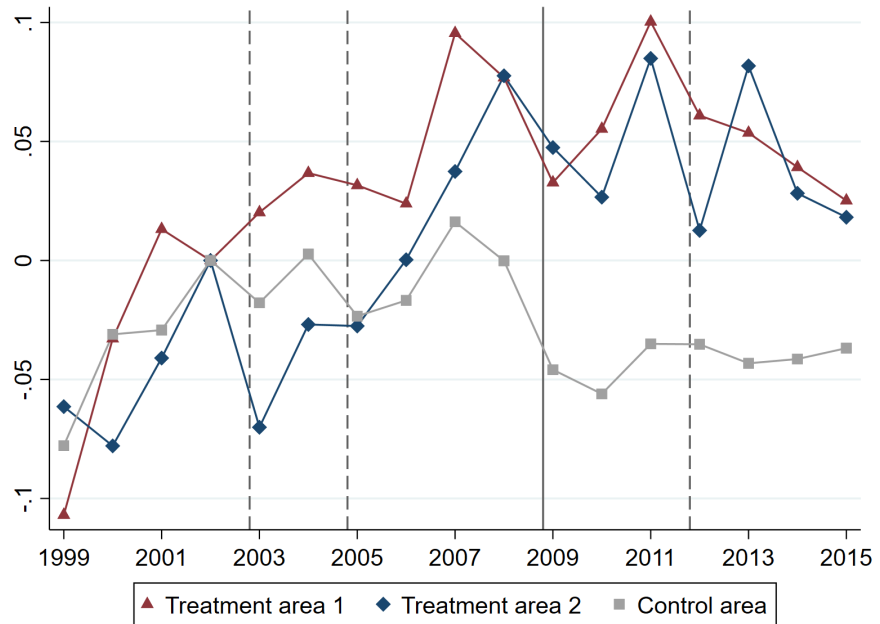

(d) Labor Input in Months

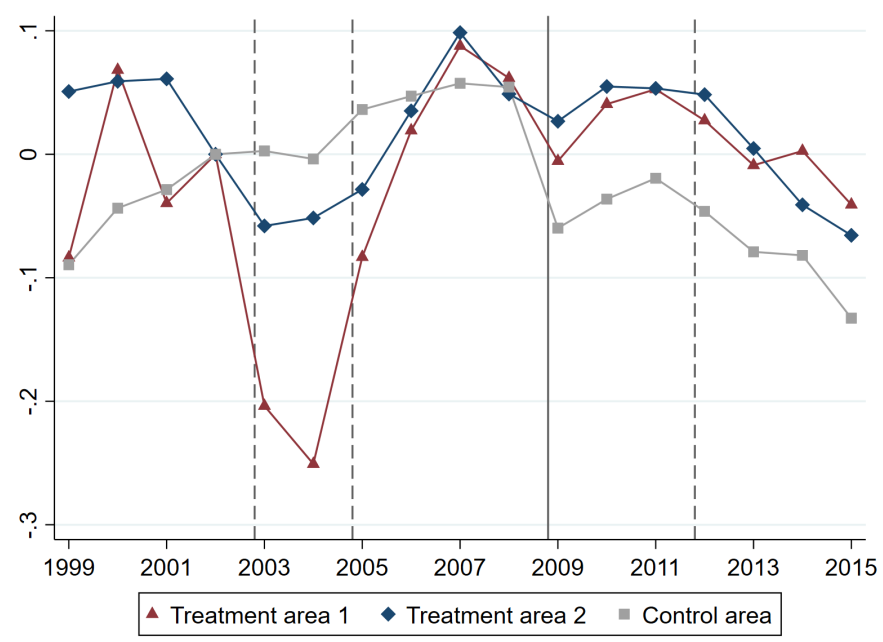

Note: These figures plot the coefficients from a regression of payroll taxes, total posted wages, number of employees and labor input in months on year dummies weighted by pre-reform firm-level labor costs relative to year 2002 separately for the control and treatment regions. The first and second dashed vertical lines correspond to the start of the first and second waves of the payroll tax experiments. The third dashed vertical line corresponds to the end of both waves of the experiment. The solid vertical line corresponds to the onset of the 2009 recession in Finland. 
Figure 4: Firm-level payroll taxes, total posted wages, number of workers and labor inputs (DD Estimates)

(a) Payroll Taxes

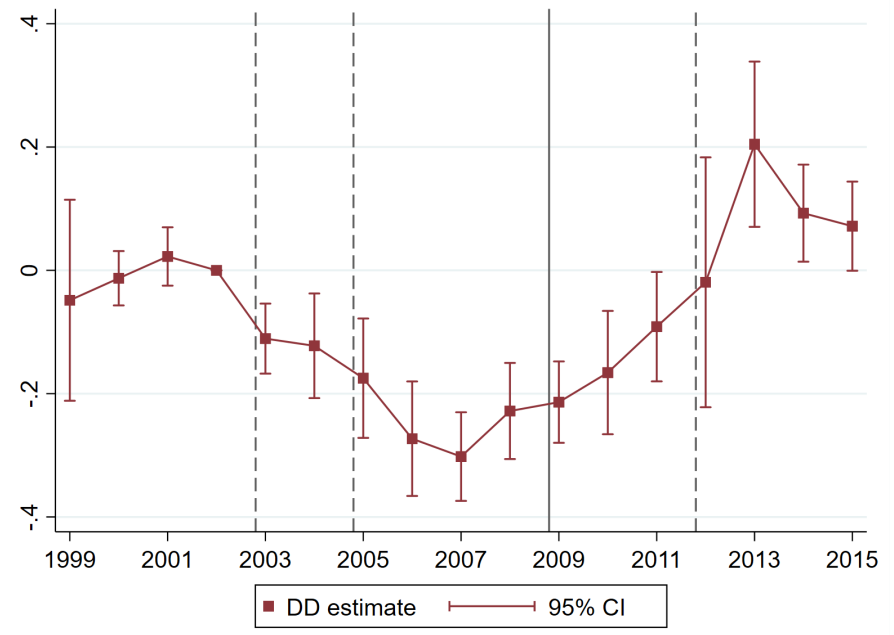

(c) Number of Employees (Full Time Equivalent)

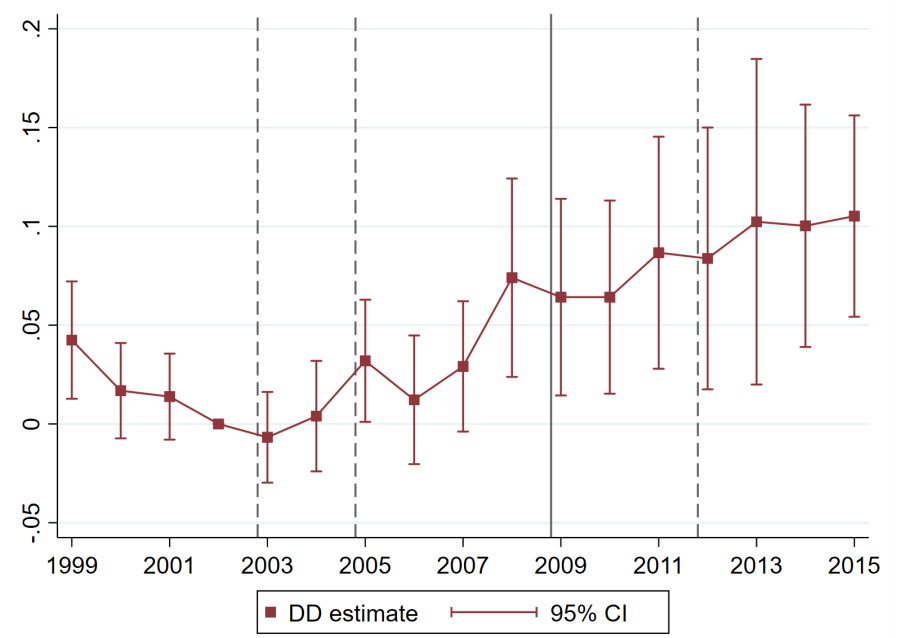

(b) Total Posted Wages

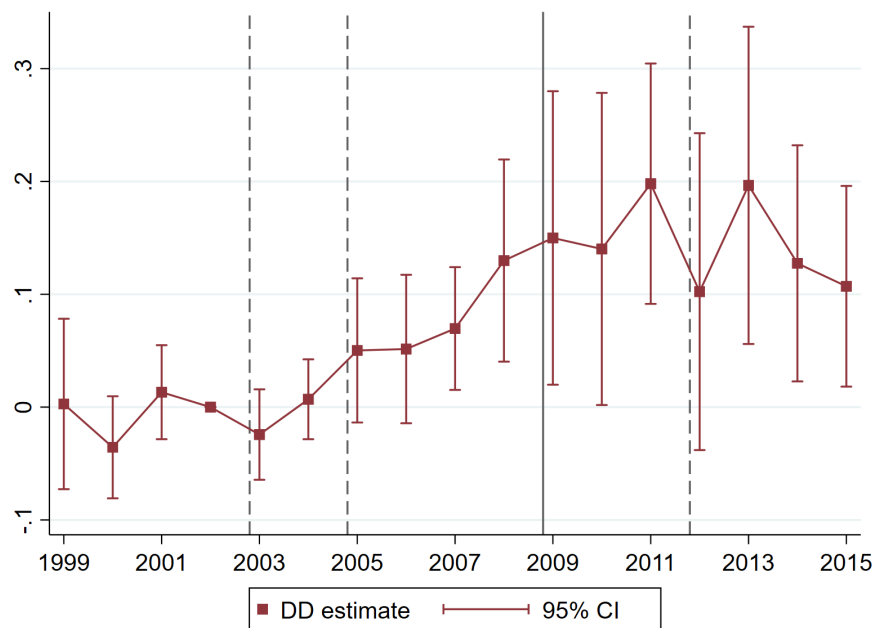

(d) Labor Input in Months

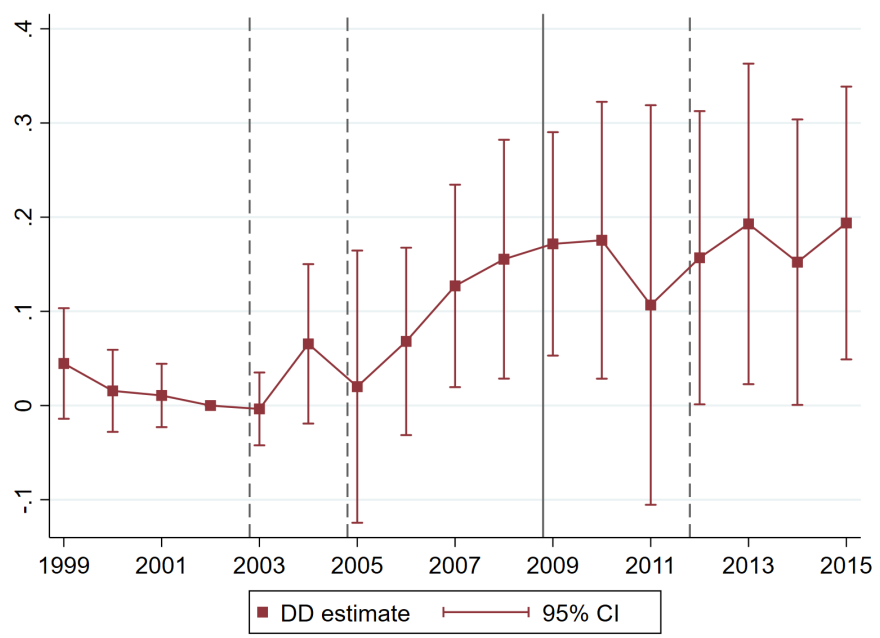

Note: These figures plot the difference-in-difference coefficients from a regression of payroll taxes, total posted wages (cost of employees net of the employer portion of payroll taxes), number of employees and labor inputs on year dummies weighted by pre-reform firm-level labor costs relative to year 2002 and including industry-year fixed effects to account for sectoral dynamics. The first and second dashed vertical lines correspond to the start of the first and second waves of the payroll tax experiments. The third dashed vertical line corresponds to the end of both waves of the experiment. The solid vertical line corresponds to the onset of the 2009 recession in Finland. 
Figure 5: Firm-level annual sales, inputs, investments and profits

(a) Sales

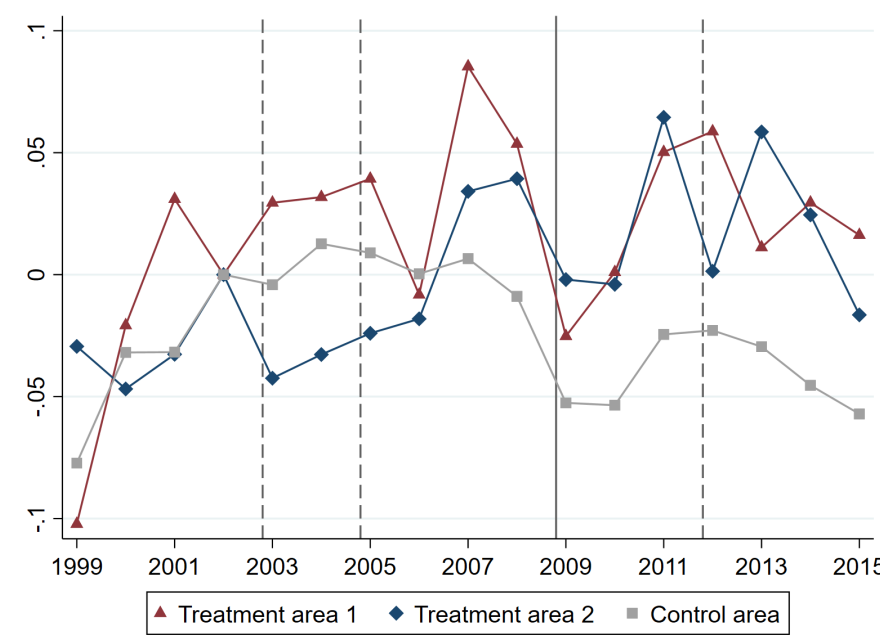

(c) Investment

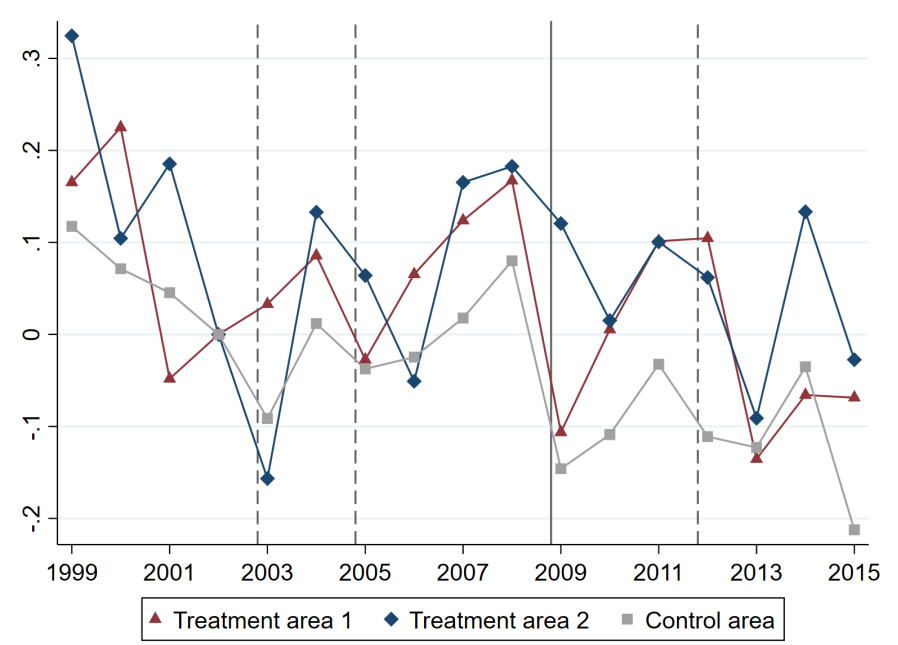

(b) Variable Costs

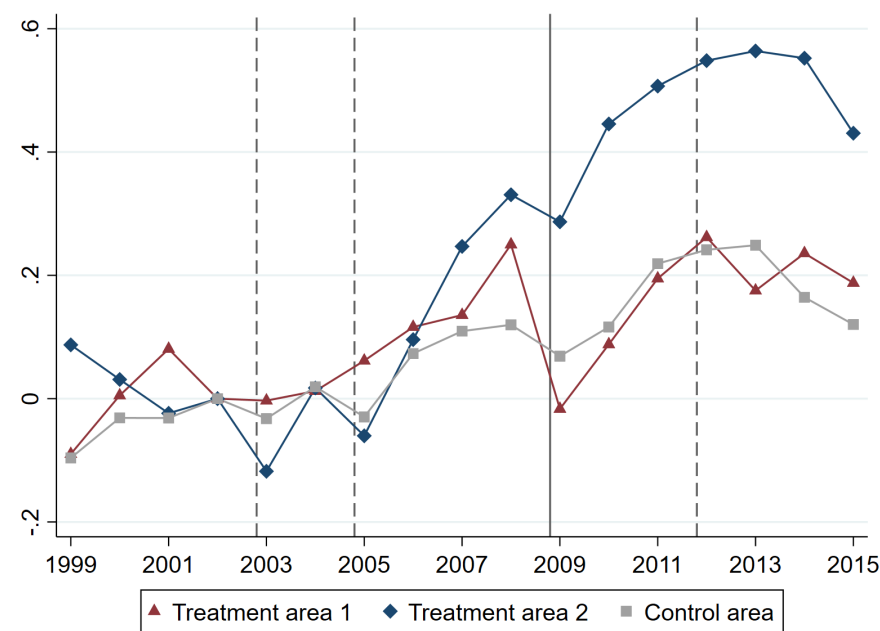

(d) Profits

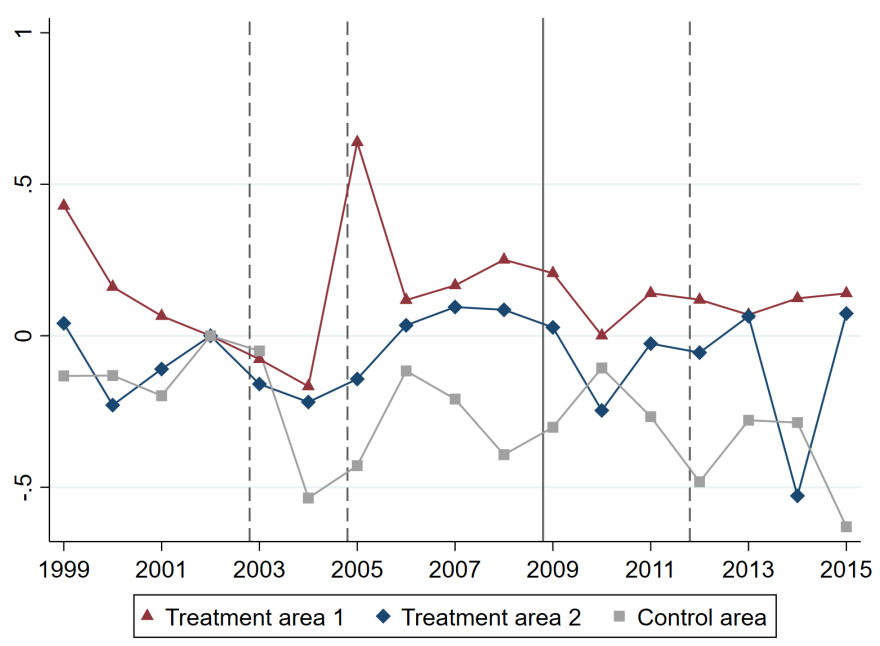

Note: These figures plot the coefficients from a regression of sales, variable costs, investments and profits on year dummies weighted by pre-reform firm-level labor costs relative to year 2002. The first and second dashed vertical lines correspond to the start of the first and second waves of the payroll tax experiments. The third dashed vertical line corresponds to the end of both waves of the experiment. The solid vertical line corresponds to the onset of the 2009 recession in Finland. 
Figure 6: Firm-level annual sales, inputs, investments and profits (DD Estimates)

(a) Sales

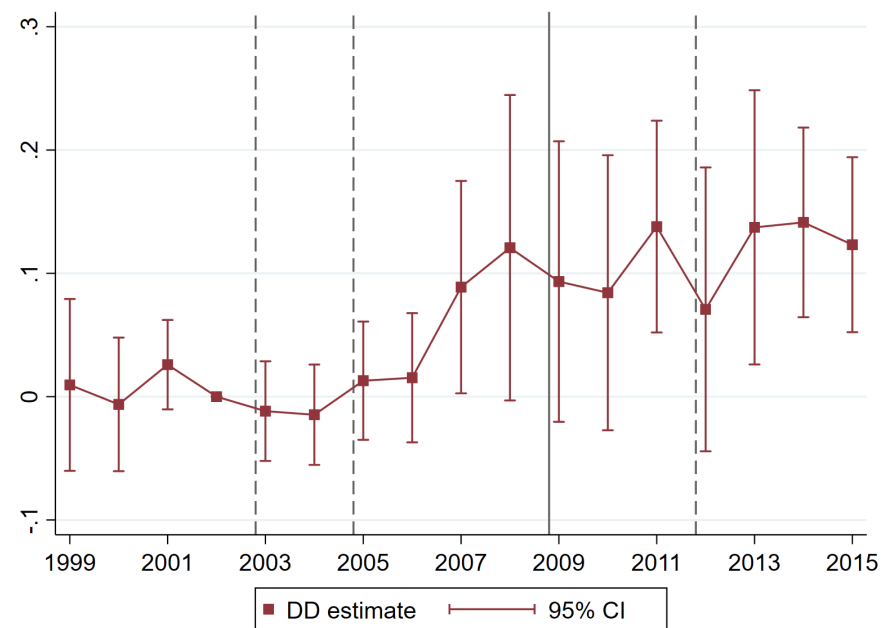

(c) Investments

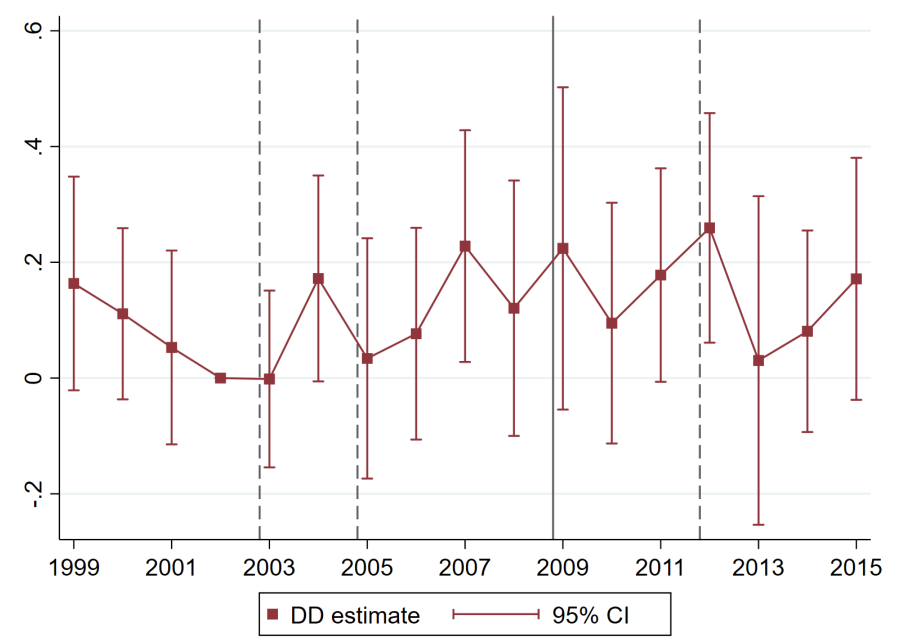

(b) Variable Costs

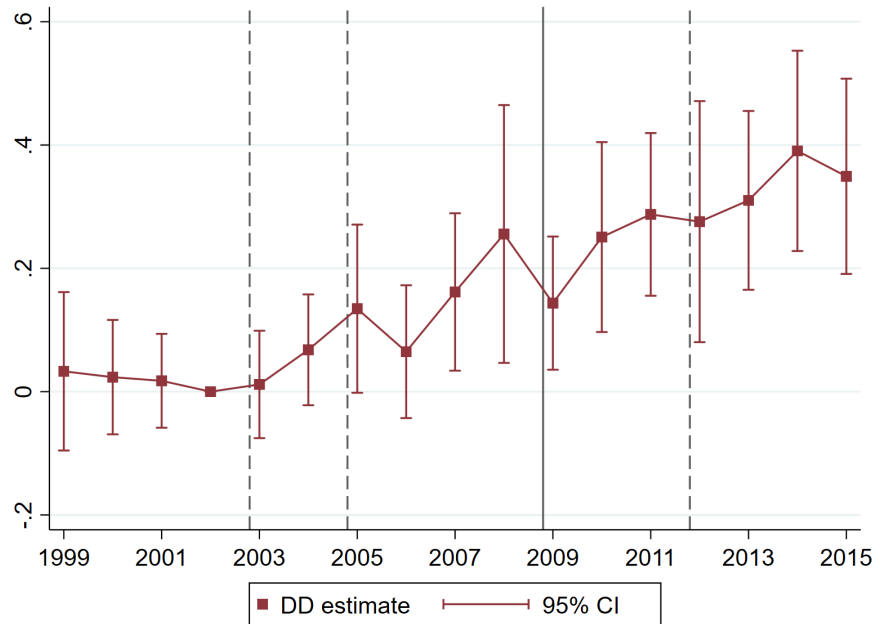

(d) Profits

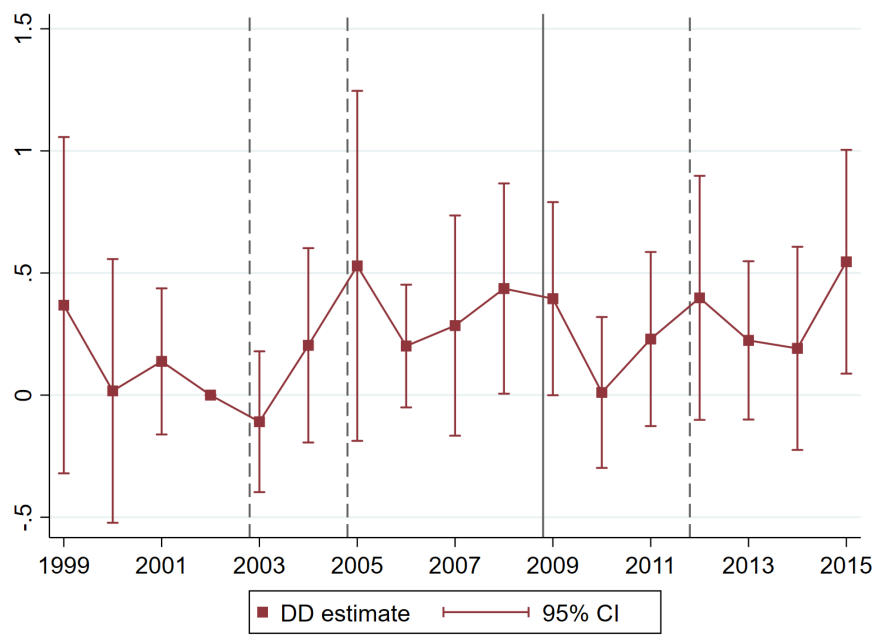

Note:These figures plot the difference-in-difference coefficients from a regression of sales, variable costs, investments and profits on year dummies weighted by pre-reform firm-level labor costs relative to year 2002 and including industry-year fixed effects to account for sectoral dynamics. The first and second dashed vertical lines correspond to the start of the first and second waves of the payroll tax experiments. The third dashed vertical line corresponds to the end of both waves of the experiment. The solid vertical line corresponds to the onset of the 2009 recession in Finland. 
Figure 7: Annual employee earnings

(a) Individual Earnings

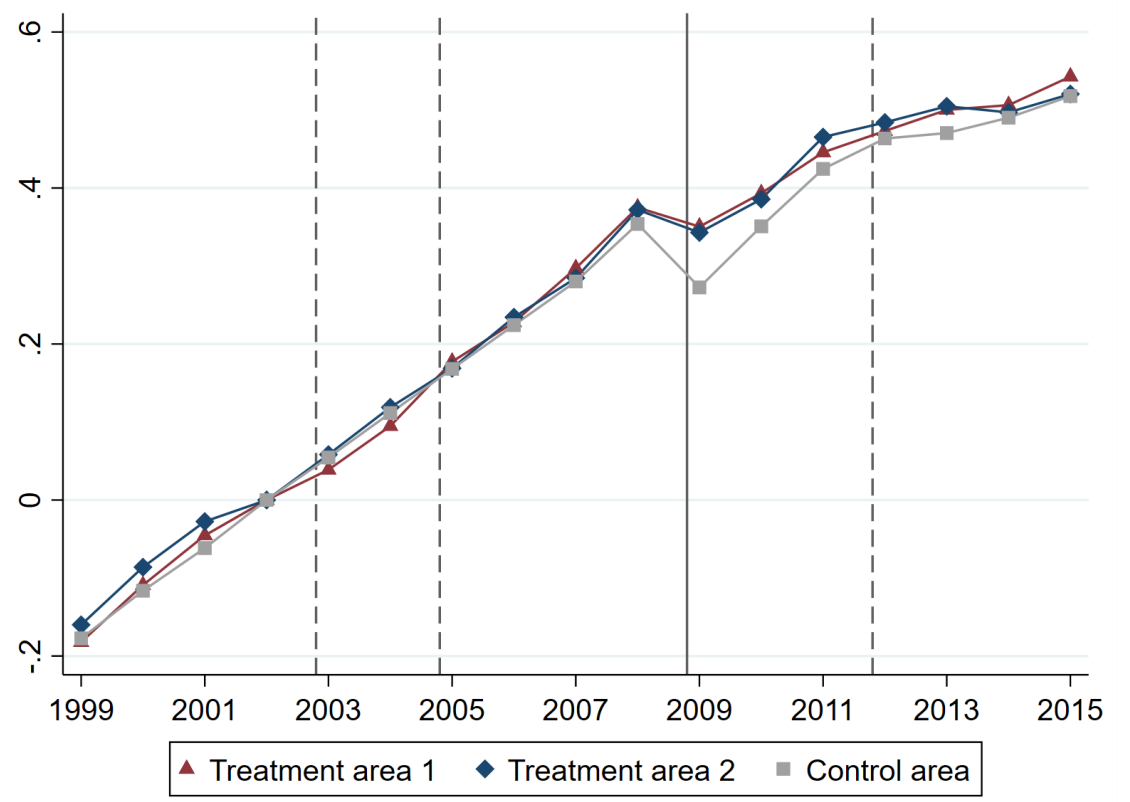

(b) Individual Earnings (DD Estimate)

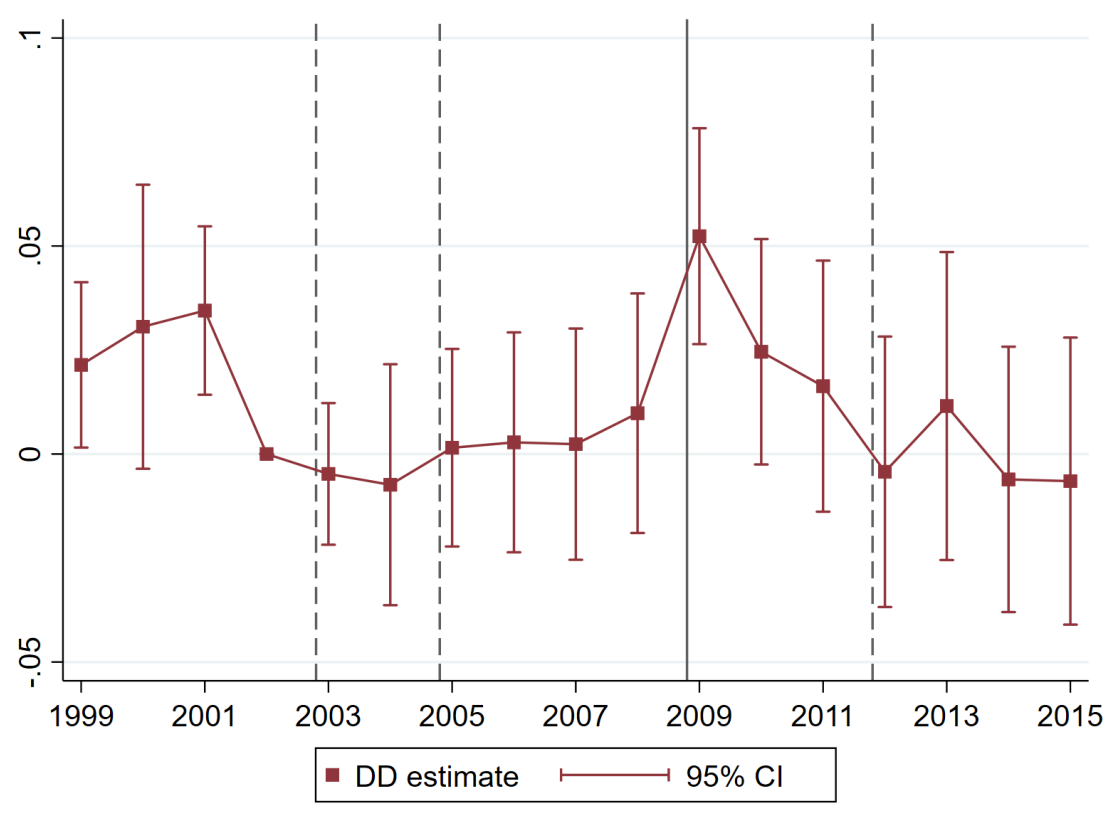

Note: The first panel plots the unconditional mean of individual-level earnings over time. The second panel plots the coefficients from a difference-in-difference regression of individual-level earnings on year dummies weighted by pre-reform firm-level labor costs relative to year 2002 and including industry-year fixed effects to account for the sectoral dynamics. The first and second dashed vertical lines correspond to the start of the first and second waves of the payroll tax experiments. The third dashed vertical line corresponds to the end of both waves of the experiment. The solid vertical line corresponds to the onset of the 2009 recession in Finland. 
Figure 8: Annual earnings by worker characteristics

(a) Men

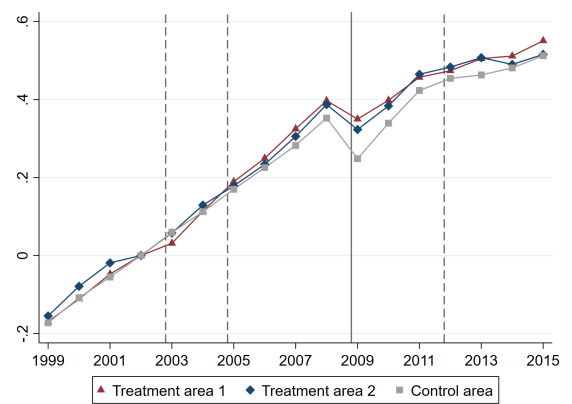

(c) College Graduates

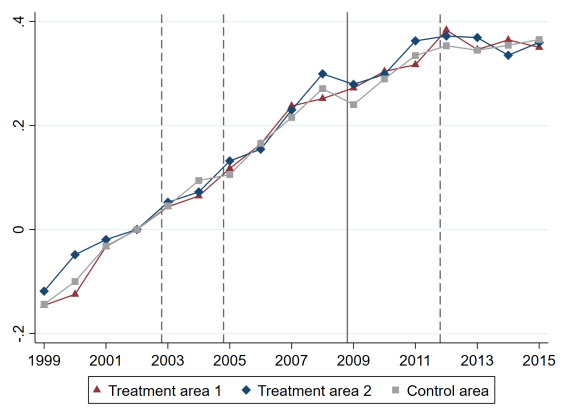

(e) Upper-Level Workers

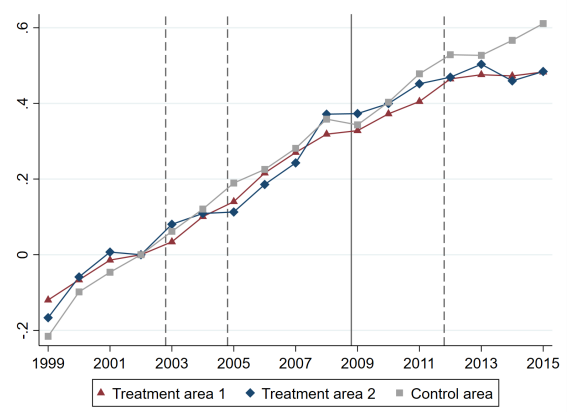

(b) Women

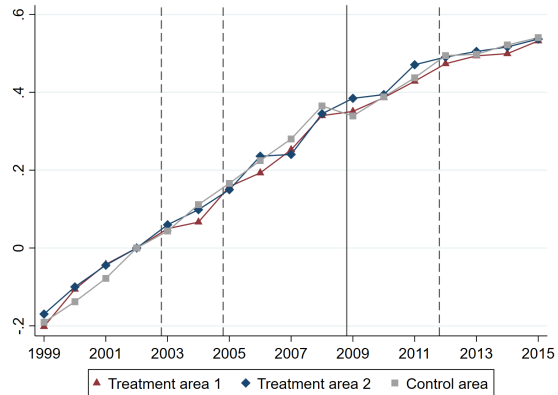

(d) Non-College Graduates

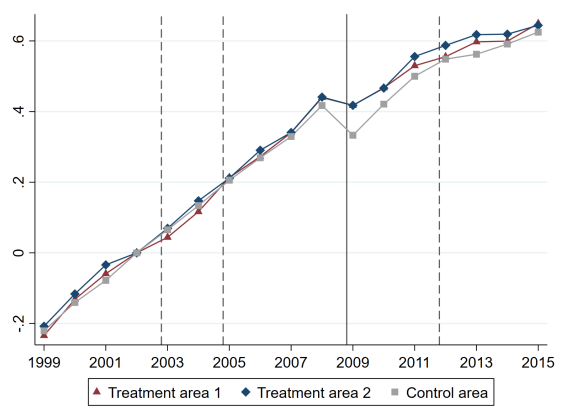

(f) Lower-Level Workers

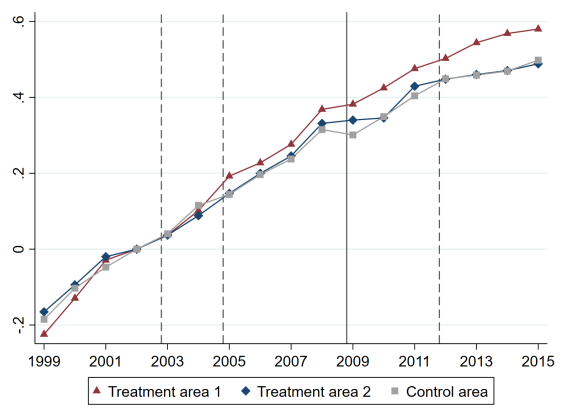

(g) Manual Workers

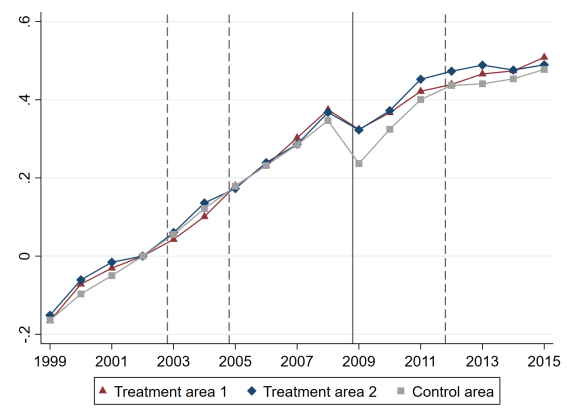

Note: These figures plot the coefficients from a regression of individual earnings of men, women, college graduates, non-college graduates, upper-level workers, lower-level workers and manual workers on year dummies weighted by pre-reform firm-level labor costs relative to year 2002. The first and second dashed vertical lines correspond to the start of the first and second waves of the payroll tax experiments. The third dashed vertical line corresponds to the end of both waves of the experiment. The solid vertical line corresponds to the onset of the 2009 recession in Finland. 
Figure 9: Annual earnings by worker characteristics (DD Estimates)

(a) Men

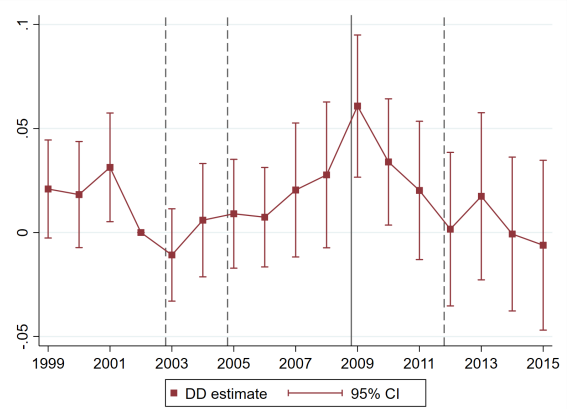

(c) College Graduates

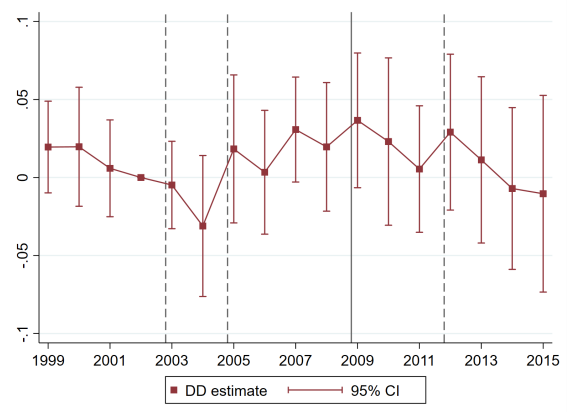

(e) Upper-Level Workers

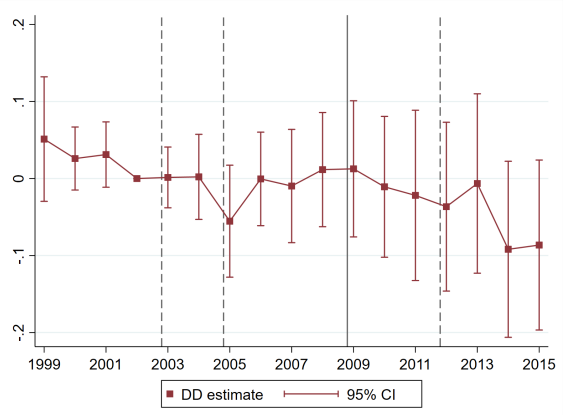

(b) Women

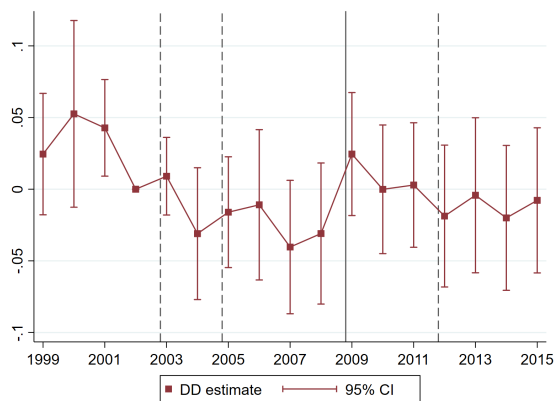

(d) Non-College Graduates

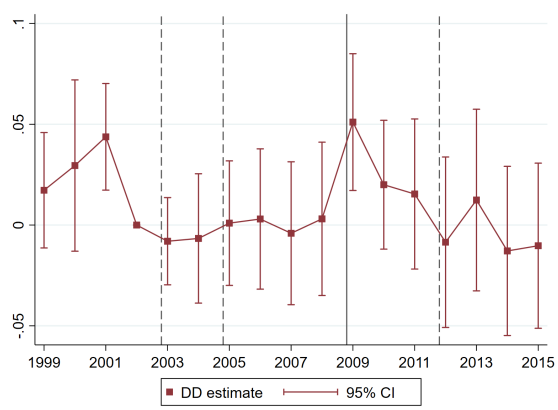

(f) Lower-Level Workers

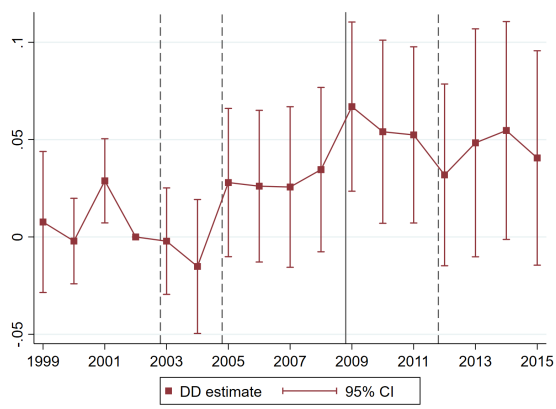

(g) Manual Workers

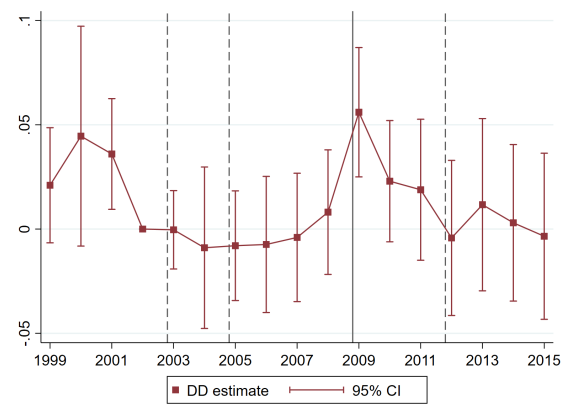

Note: These figures plot the coefficients from a regression of individual earnings of men, women, college graduates, non-college graduates, upper-level workers, lower-level workers and manual workers on year dummies weighted by pre-reform firm-level labor costs relative to year 2002 and including industry-year fixed effects to account for the sectoral dynamics. The first and second dashed vertical lines correspond to the start of the first and second waves of the payroll tax experiments. The third dashed vertical line corresponds to the end of both waves of the experiment. The solid vertical line corresponds to the onset of the 2009 recession in Finland. 
Figure 10: Number of employees by worker characteristics

(a) Men

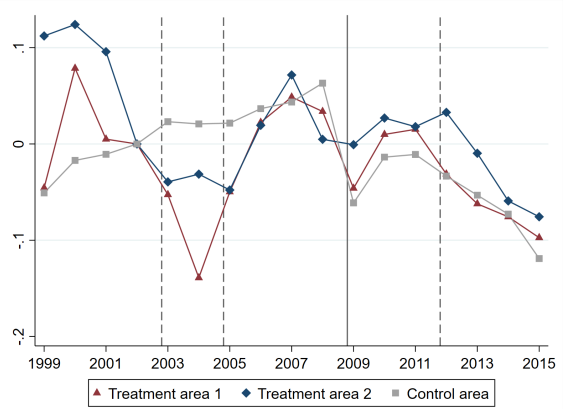

(c) College Graduates

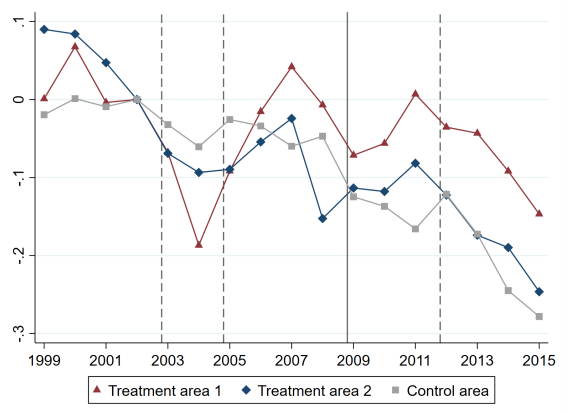

(e) Upper-Level Workers

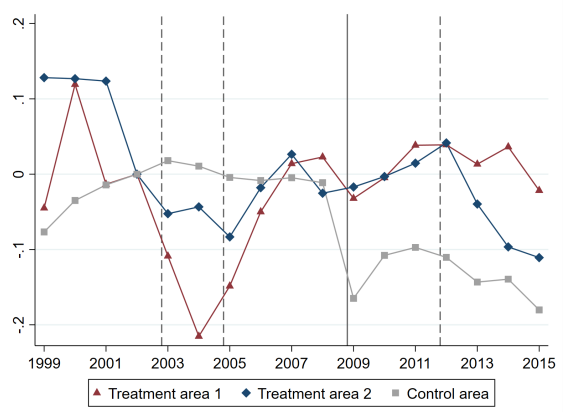

(b) Women

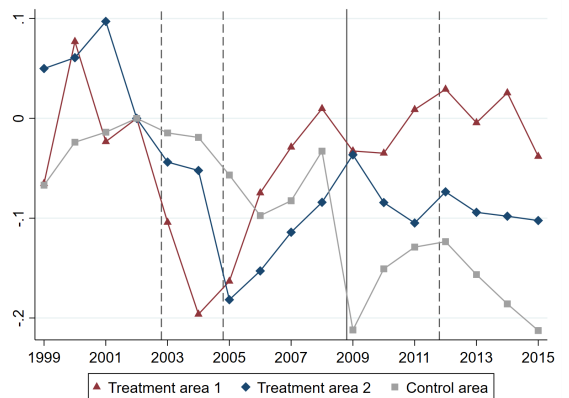

(d) Non-College Graduates

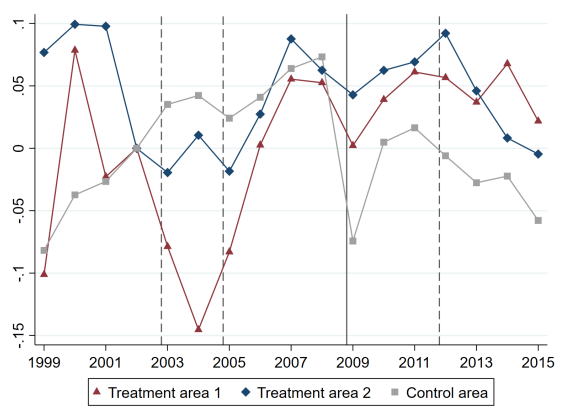

(f) Lower-Level Workers

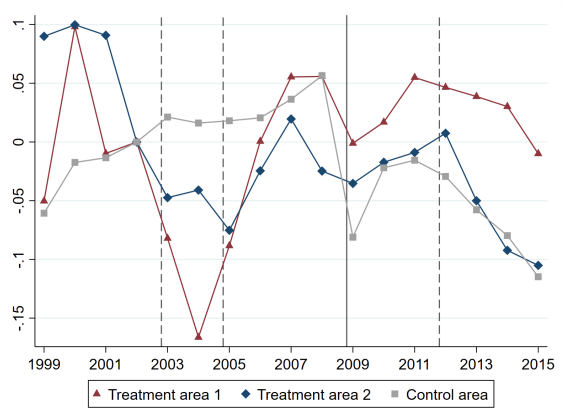

(g) Manual Workers

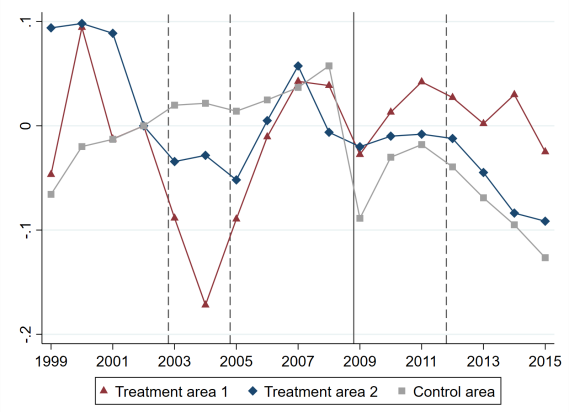

Note: These figures plot the coefficients from a regression of the number of men, women, college graduates, non-college graduates, upper-level, lower-level and manual workers on year dummies weighted by pre-reform firm-level labor costs relative to year 2002. The first and second dashed vertical lines correspond to the start of the first and second waves of the payroll tax experiments. The third dashed vertical line corresponds to the end of both waves of the experiment. The solid vertical line corresponds to the onset of the 2009 recession in Finland. 
Figure 11: Number of employees by worker characteristics (DD Estimates)

(a) Men

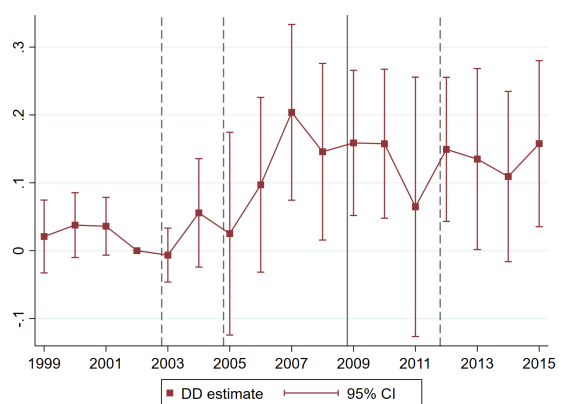

(c) College Graduates

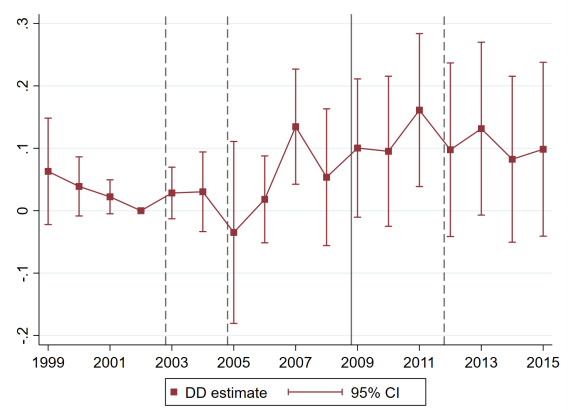

(e) Upper-Level Workers

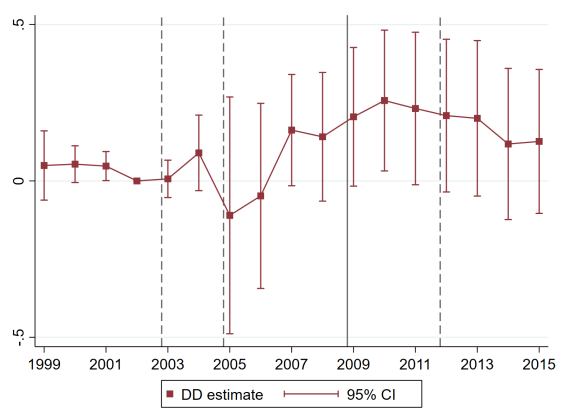

(b) Woemn

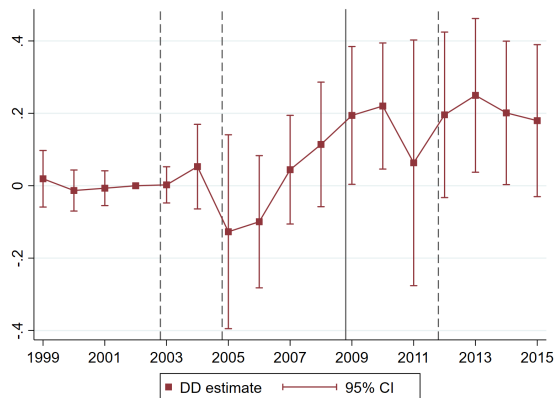

(d) Non-College Graduates

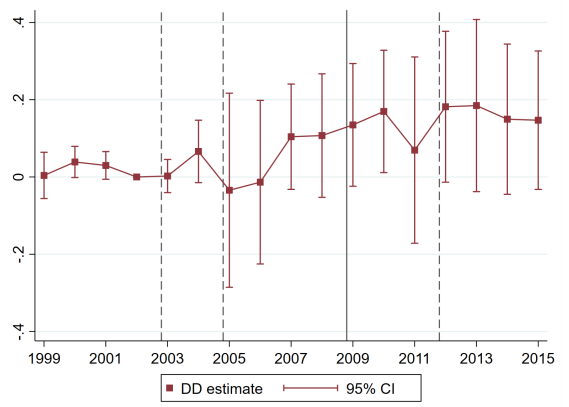

(f) Lower-Level Workers

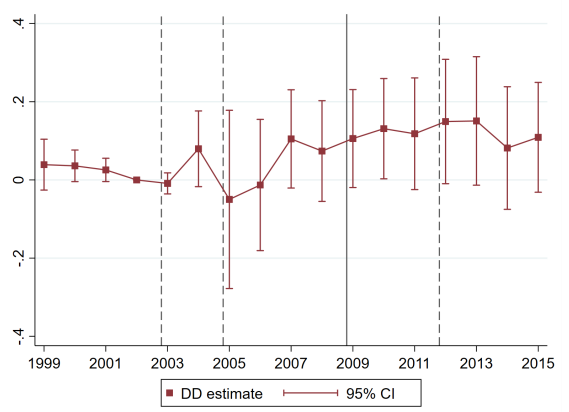

(g) Manual Workers

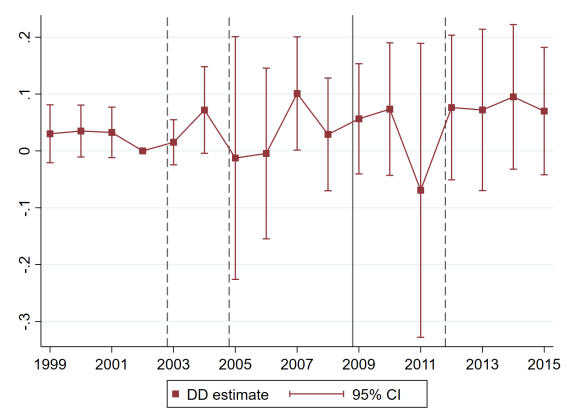

Note: These figures plot the coefficients from a regression of the number of men, women, college graduates, non-college graduates, upper-level, lower-level and manual workers on year dummies weighted by pre-reform firm-level labor costs relative to year 2002 and including industry-year fixed effects to account for the sectoral dynamics. The first and second dashed vertical lines correspond to the start of the first and second waves of the payroll tax experiments. The third dashed vertical line corresponds to the end of both waves of the experiment. The solid vertical line corresponds to the 29 onset of the 2009 recession in Finland. 
Table 1: Firm-level descriptive statistics in year 2002

\begin{tabular}{|c|c|c|c|c|c|c|c|c|c|}
\hline \multirow{4}{*}{ Experiment 1} & $\begin{array}{c}\text { VARIABLES } \\
\text { Stats }\end{array}$ & Payroll taxes & Labor costs & No. empl. & $\begin{array}{l}\text { No. empl. } \\
\text { full-time }\end{array}$ & $\begin{array}{l}\text { No. empl. } \\
\text { part-time }\end{array}$ & Average wages & Turnover & Profits \\
\hline & Mean & 4191 & 43679 & 3.8 & .54 & 2.9 & 9518 & 259674 & 24463 \\
\hline & Median & 1628 & 14873 & 2 & 0 & 2 & 7315 & 128870 & 16594 \\
\hline & SD & 6225 & 68980 & 3.7 & .82 & 2.7 & 8791 & 300759 & 28096 \\
\hline \multirow{4}{*}{ Experiment 2} & $\mathrm{~N}$ & 1719 & 2089 & 2089 & 2089 & 2089 & 1769 & 1950 & 1727 \\
\hline & Mean & 5391 & 56254 & 4.3 & .7 & 3.1 & 11025 & 291109 & 27626 \\
\hline & Median & 2329 & 20882 & 3 & 0 & 2 & 9071 & 161714 & 19396 \\
\hline & SD & 7065 & 79600 & 3.8 & .88 & 2.8 & 9325 & 309437 & 29940 \\
\hline \multirow{5}{*}{ Control } & $\mathrm{N}$ & 1557 & 1890 & 1890 & 1890 & 1890 & 1683 & 1767 & 1660 \\
\hline & Mean & 5394 & 51614 & 4.1 & .64 & 3 & 10422 & 282755 & 29483 \\
\hline & Median & 2236 & 18167 & 3 & 0 & 2 & 8002 & 150820 & 20734 \\
\hline & SD & 7146 & 77410 & 3.8 & .85 & 2.8 & 9459 & 310350 & 30427 \\
\hline & $\mathrm{N}$ & 5100 & 6268 & 6268 & 6268 & 6268 & 5484 & 5758 & 5346 \\
\hline
\end{tabular}

Note: This table shows the firm-level mean, median, standard deviation and number of observations of payroll taxes, labor costs, number of employees, number of full time employees, number of part time employees, average wages, sales (turnover) and profits. 
Table 2: Average firm-level responses to the payroll tax experiments and to the Great Recession (weighted by firm-level labor costs)

\begin{tabular}{|c|c|c|c|c|}
\hline $\begin{array}{l}\text { VARIABLES } \\
\text { in logs }\end{array}$ & $\begin{array}{c}(1) \\
\text { Payroll } \\
\text { taxes }\end{array}$ & $\begin{array}{c}\text { (2) } \\
\text { Labor costs } \\
\text { net of payroll taxes }\end{array}$ & $\begin{array}{c}(3) \\
\text { Number of } \\
\text { workers }\end{array}$ & $\begin{array}{l}\text { (4) } \\
\text { Labor input } \\
\text { in months }\end{array}$ \\
\hline$\alpha_{2}\left(A_{i} *\right.$ Recession $\left._{t}\right)$ & $\begin{array}{l}0.068^{* *} \\
(0.033)\end{array}$ & $\begin{array}{c}0.075^{* * *} \\
(0.024)\end{array}$ & $\begin{array}{c}0.075^{* *} \\
(0.037)\end{array}$ & $\begin{array}{l}0.072^{*} \\
(0.040)\end{array}$ \\
\hline$\alpha_{3}\left(A_{i} * \operatorname{Exp}_{1 t}\right)$ & $\begin{array}{c}-0.305^{* * *} \\
(0.040)\end{array}$ & $\begin{array}{c}0.034 \\
(0.026)\end{array}$ & $\begin{array}{c}0.054 \\
(0.043)\end{array}$ & $\begin{array}{c}0.055 \\
(0.044)\end{array}$ \\
\hline$\alpha_{4}\left(A_{i} * \operatorname{Exp}_{2 t}\right)$ & $\begin{array}{l}-0.087 \\
(0.054)\end{array}$ & $\begin{array}{c}0.005 \\
(0.036)\end{array}$ & $\begin{array}{c}0.077 \\
(0.069)\end{array}$ & $\begin{array}{c}0.077 \\
(0.072)\end{array}$ \\
\hline $\begin{array}{l}\text { Cumulative effect } \\
\text { p value }\end{array}$ & $\begin{array}{c}-0.326 \\
0.001\end{array}$ & $\begin{array}{l}0.111 \\
0.098\end{array}$ & $\begin{array}{l}0.206 \\
0.079\end{array}$ & $\begin{array}{l}0.203 \\
0.082\end{array}$ \\
\hline Observations & 56,207 & 69,701 & 73,512 & 73,461 \\
\hline R-squared & 0.053 & 0.011 & 0.084 & 0.055 \\
\hline
\end{tabular}

Note: This table shows the results of estimating specification (1) with firm-, year-, and industry-year fixed effects on payroll taxes, labor costs net of payroll taxes, number of workers and labor inputs in months. We use data from 1999 to 2015 in these estimations, Exp refers to one in years 2003 to 2011 (first treatment wave) and 2005 to 2011 (second treatment wave), Exp is two for years 2012 to 2015, and zero otherwise. A refers to a dummy equal to one if a firm is located in the treated municipalities, and zero otherwise. The standard errors in parentheses are clustered at the municipality level. 
Table 3: Average firm-level responses to the payroll tax experiments and to the Great Recession (weighted by sector-level revenue)

\begin{tabular}{ccccc}
\hline VARIABLES & $(1)$ & $(2)$ & $(3)$ & $(4)$ \\
in logs & Payroll & Labor costs & Number of & Labor input \\
& taxes & net of payroll taxes & workers & in months \\
\cline { 2 - 5 }$\alpha_{2}\left(A_{i} *\right.$ Recession $\left._{t}\right)$ & $0.097^{* *}$ & $0.072^{* *}$ & $0.112^{* * *}$ & $0.122^{* * *}$ \\
& $(0.039)$ & $(0.031)$ & $(0.046)$ & $(0.047)$ \\
\cline { 2 - 5 }$\alpha_{3}\left(A_{i} *\right.$ Exp $\left._{1 t}\right)$ & $-0.437^{* * *}$ & -0.113 & 0.074 & 0.098 \\
& $(0.039)$ & $(0.070)$ & $(0.053)$ & $(0.067)$ \\
$\alpha_{4}\left(A_{i} *\right.$ Exp $\left._{2 t}\right)$ & $-0.168^{* * *}$ & 0.091 & 0.027 & 0.088 \\
& $(0.045)$ & $(0.050)$ & $(0.073)$ & $(0.079)$ \\
\cline { 2 - 5 } Observations & 55,968 & 69,437 & 73,281 & 73,233 \\
R-squared & 0.126 & 0.099 & 0.101 & 0.097 \\
\hline
\end{tabular}

Note: This table shows the results of estimating specification (1) with firm-, year-, and industry-year fixed effects on payroll taxes, labor costs net of payroll taxes, number of workers and labor inputs in months. The observations are weighted by sector in order to control for sectoral differences across the control and treatment groups. We use data from 1999 to 2015 in these estimations, Exp refers to one in years 2003 to 2011 (first treatment wave) and 2005 to 2011 (second treatment wave), Exp is two for years 2012 to 2015, and zero otherwise. A refers to a dummy equal to one if a firm is located in the treated municipalities, and zero otherwise. The standard errors in parentheses are clustered at the municipality level. 
Table 4: Average firm-level responses to the payroll tax experiments and to the Great Recession (weighted by firm-level labor costs)

\begin{tabular}{lcccc}
\hline VARIABLES & $(1)$ & $(2)$ & $(3)$ & $(4)$ \\
in logs & Sales & Input usage & Investments & Profits \\
\hline$\alpha_{2}\left(A_{i} *\right.$ Recession $\left._{t}\right)$ & 0.034 & 0.042 & 0.046 & -0.115 \\
& $(0.027)$ & $(0.054)$ & $(0.064)$ & $(0.169)$ \\
\cline { 2 - 5 }$\alpha_{3}\left(A_{i} *\right.$ Exp $\left._{1 t}\right)$ & 0.0002 & $0.077^{* *}$ & 0.004 & 0.196 \\
& $(0.027)$ & $(0.033)$ & $(0.042)$ & $(0.157)$ \\
$\alpha_{4}\left(A_{i} *\right.$ Exp $\left._{2 t}\right)$ & 0.004 & $0.131^{* *}$ & -0.030 & 0.378 \\
& $(0.046)$ & $(0.051)$ & $(0.083)$ & $(0.238)$ \\
Cumulative effect & 0.038 & 0.250 & 0.020 & 0.459 \\
p value & 0.132 & 0.027 & 0.492 & 0.070 \\
Observations & 72,878 & 65,756 & 49,018 & 58,864 \\
R-squared & 0.007 & 0.012 & 0.009 & 0.013 \\
\hline
\end{tabular}

Note: This table shows the results of estimating specification (1) with firm-, year-, and industry-year fixed effects on sales, input usage, investments and profits. We use data from 1999 to 2015 in these estimations, Exp refers to one in years 2003 to 2011 (first treatment wave) and 2005 to 2011 (second treatment wave), Exp is two for years 2012 to 2015, and zero otherwise. A refers to a dummy equal to one if a firm is located in the treated municipalities, and zero otherwise. The standard errors in parentheses are clustered at the municipality level.

Table 5: Average employee-level earning responses to the payroll tax experiments and to the Great Recession

\begin{tabular}{lcccccccc}
\hline Employee earnings & $(1)$ & $(2)$ & $(3)$ & $(4)$ & $(5)$ & $(6)$ & $(7)$ & $(8)$ \\
in logs & All & Male & Female & No college degree & $\begin{array}{c}(5) \\
\text { College degree }\end{array}$ & $\begin{array}{c}\text { Upper-level } \\
\text { Lower-level }\end{array}$ & Manual \\
\cline { 2 - 9 }$\alpha_{2}\left(A_{i} *\right.$ Recession $\left._{t}\right)$ & $0.030^{* * *}$ & $0.025^{* * *}$ & $0.037^{* * *}$ & $0.032^{* * *}$ & 0.008 & 0.003 & $0.035^{* * *}$ & $0.037^{* * *}$ \\
& $(0.008)$ & $(0.009)$ & $(0.010)$ & $(0.009)$ & $(0.013)$ & $(0.026)$ & $(0.009)$ & $(0.010)$ \\
\cline { 2 - 9 }$\alpha_{3}\left(A_{i} *\right.$ Exp $\left._{1 t}\right)$ & -0.021 & -0.008 & $-0.047^{* *}$ & -0.025 & -0.002 & -0.038 & 0.007 & -0.029 \\
& $(0.014)$ & $(0.013)$ & $(0.019)$ & $(0.016)$ & $(0.017)$ & $(0.030)$ & $(0.014)$ & $(0.019)$ \\
$\alpha_{4}\left(A_{i} *\right.$ Exp $\left._{2 t}\right)$ & $-0.050^{* * *}$ & $-0.040^{* *}$ & $-0.067^{* * *}$ & $-0.055^{* * *}$ & -0.017 & $-0.076^{*}$ & -0.004 & $-0.059^{* *}$ \\
& $(0.017)$ & $(0.017)$ & $(0.024)$ & $(0.021)$ & $(0.024)$ & $(0.038)$ & $(0.018)$ & $(0.022)$ \\
Cumulative effect & -0.041 & -0.024 & -0.078 & -0.048 & -0.010 & -0.112 & 0.038 & -0.050 \\
p value & 0.154 & 0.408 & 0.059 & 0.154 & 0.800 & 0.180 & 0.245 & 0.171 \\
Observations & $1,230,430$ & 834,310 & 396,120 & 906,898 & 146,599 & 88,213 & 275,559 & 727,677 \\
R-squared & 0.061 & 0.070 & 0.050 & 0.081 & 0.052 & 0.079 & 0.060 & 0.060 \\
\hline
\end{tabular}

Note: This table shows the result of estimating specification (1) with employee-, year-, and industry-year effects on earnings of male, female, non-college graduates, college graduates, upper-level, lower-level and manual workers. We use data from 1999 to 2015 in these estimations, Exp refers to one in years 2003 to 2011 (first treatment wave) and 2005 to 2011 (second treatment wave), Exp is two for years 2012 to 2015, and zero otherwise. A refers to a dummy equal to one if an employee works in a firm located in the treated municipalities, and zero otherwise. The standard errors in parentheses are clustered at the municipality level. 
Table 6: Average firm-level employment responses to the payroll tax experiments and to the Great Recession (weighted by firm-level labor costs)

\begin{tabular}{|c|c|c|c|c|c|c|c|c|}
\hline \multirow{2}{*}{$\begin{array}{l}\text { Number of workers } \\
\text { in logs }\end{array}$} & (1) & $(2)$ & (3) & (4) & $(5)$ & (6) & (7) & (8) \\
\hline & All & Female & Male & College degree & No college degree & Upper-level & Lower-level & Manual \\
\hline \multirow{2}{*}{$\alpha_{2}\left(A_{i} *\right.$ Recession $\left._{t}\right)$} & $0.074^{* *}$ & $0.160^{* *}$ & 0.028 & $0.076^{* *}$ & $0.079^{*}$ & $0.179^{* * *}$ & $0.081^{* * *}$ & -0.014 \\
\hline & $(0.037)$ & $(0.063)$ & $(0.030)$ & $(0.033)$ & $(0.042)$ & $(0.048)$ & $(0.021)$ & $(0.042)$ \\
\hline \multirow{2}{*}{$\alpha_{3}\left(A_{i} * \operatorname{Exp}_{1 t}\right)$} & 0.055 & -0.003 & 0.067 & 0.006 & 0.023 & 0.006 & 0.008 & 0.010 \\
\hline & $(0.043)$ & $(0.070)$ & $(0.047)$ & $(0.039)$ & $(0.068)$ & $(0.098)$ & $(0.058)$ & $(0.050)$ \\
\hline \multirow[t]{2}{*}{$\alpha_{4}\left(A_{i} * \operatorname{Exp}_{2 t}\right)$} & 0.079 & 0.044 & 0.077 & -0.008 & 0.063 & -0.058 & 0.013 & 0.066 \\
\hline & $(0.068)$ & $(0.088)$ & $(0.063)$ & $(0.060)$ & $(0.085)$ & $(0.112)$ & $(0.070)$ & $(0.067)$ \\
\hline \multirow{2}{*}{$\begin{array}{l}\text { Cumulative effect } \\
\text { p value }\end{array}$} & 0.208 & 0.201 & 0.172 & 0.074 & 0.165 & 0.127 & 0.102 & 0.062 \\
\hline & 0.075 & 0.253 & 0.091 & 0.494 & 0.303 & 0.551 & 0.440 & 0.549 \\
\hline Observations & 73,511 & 45,306 & 64,789 & 34,330 & 66,485 & 25,607 & 44,361 & 49,025 \\
\hline R-squared & 0.084 & 0.079 & 0.089 & 0.109 & 0.060 & 0.087 & 0.077 & 0.051 \\
\hline
\end{tabular}

Note: This table shows the result of estimating specification (1) with firm-, year-, and industry-year fixed effects on the employment response of male, female, college graduate, non-college graduate, upper-level, lower-level and manual workers. We use data from 1999 to 2015 in these estimations, Exp refers to one in years 2003 to 2011 (first treatment wave) and 2005 to 2011 (second treatment wave), Exp is two for years 2012 to 2015, and zero otherwise. A refers to a dummy equal to one if a firm is located in the treated municipalities, and zero otherwise. The standard errors in parentheses are clustered at the municipality level. 
Table 7: Responses by liquidity constraints

\begin{tabular}{lccccc}
\hline Number of workers & \multicolumn{5}{c}{ Liquidity constraint quintiles } \\
in logs & 1 st & 2nd & 3rd & 4 th & 5th \\
\hline$\alpha_{2}\left(A_{i} *\right.$ Recession $\left._{t}\right)$ & -0.004 & -0.017 & 0.012 & 0.022 & $0.125^{* *}$ \\
& $(0.035)$ & $(0.039)$ & $(0.046)$ & $(0.081)$ & $(0.049)$ \\
\cline { 2 - 6 }$\alpha_{3}\left(A_{i} * \operatorname{Exp}_{1 t}\right)$ & 0.014 & -0.024 & $0.043^{*}$ & -0.006 & -0.038 \\
& $(0.039)$ & $(0.026)$ & $(0.023)$ & $(0.035)$ & $(0.057)$ \\
$\alpha_{4}\left(A_{i} * \operatorname{Exp}_{2 t}\right)$ & 0.031 & -0.040 & $0.076^{*}$ & 0.009 & 0.045 \\
& $(0.057)$ & $(0.050)$ & $(0.040)$ & $(0.066)$ & $(0.111)$ \\
\cline { 2 - 6 } & 11,356 & 13,327 & 14,109 & 14,618 & 11,700 \\
Observations & 0.105 & 0.078 & 0.147 & 0.144 & 0.137 \\
\hline
\end{tabular}

Note: The coefficients show the effects on firm-level outcomes in the treated versus control regions. The first quintile corresponds to firms with the most funds and the fifth quintile to those that are the most liquidity constrained. The coefficients are estimated using specification (1) with firm-, year-, and industry-year fixed effects and estimate the effects by pre-reform liquidity constraint quintiles that we measure by liquid assets divided by total assets. We use data from 1999 to 2015, Exp refers to one in years 2003-2011 for the first treatment wave and 2005-2011 for the second treatment wave, Exp is two for years 2012-2015, and zero otherwise. A refers to all firms located in experiment municipalities, and zero otherwise. The standard errors in parentheses are clustered at the municipality level. 


\section{Appendix A}

Table 8: Social insurance contribution rates by firm categories, insurance program and years

\begin{tabular}{|c|c|c|c|c|c|c|c|c|c|c|}
\hline \multirow[b]{2}{*}{ Year } & \multicolumn{3}{|c|}{$\begin{array}{c}\text { National health and pension } \\
\text { insurances } \\
\text { Firm categories* }\end{array}$} & \multirow[t]{2}{*}{$\begin{array}{l}\text { Accident } \\
\text { insur.*** }\end{array}$} & \multicolumn{2}{|c|}{$\begin{array}{c}\text { Unemployment } \\
\text { insurances } \\
\text { Firm categories** }\end{array}$} & \multirow[t]{2}{*}{$\begin{array}{l}\text { Group life } \\
\text { insur.*** }\end{array}$} & \multirow[t]{2}{*}{$\begin{array}{c}\text { Employees } \\
\text { pensions*** }\end{array}$} & \multicolumn{2}{|c|}{ Total } \\
\hline & I & II & III & & I & II & & & low & high \\
\hline 1996 & 4.000 & 5.600 & 6.500 & 1.2 & 1.00 & 4.00 & 0.100 & 16.80 & 23.100 & 28.600 \\
\hline 1997 & 4.000 & 5.600 & 6.500 & 1.4 & 1.00 & 4.00 & 0.090 & 16.70 & 23.190 & 28.690 \\
\hline 1998 & 4.000 & 5.600 & 6.500 & 1.4 & 0.90 & 3.90 & 0.080 & 16.80 & 23.180 & 28.680 \\
\hline 1999 & 4.000 & 5.600 & 6.500 & 1.3 & 0.90 & 3.85 & 0.080 & 16.80 & 23.080 & 28.530 \\
\hline 2000 & 4.000 & 5.600 & 6.500 & 1.2 & 0.90 & 3.45 & 0.090 & 16.80 & 22.990 & 28.040 \\
\hline $7 / 2000$ & 3.600 & 5.600 & 6.500 & 1.2 & 0.90 & 3.45 & 0.090 & 16.80 & 22.590 & 28.040 \\
\hline 2001 & 3.600 & 5.600 & 6.500 & 1.2 & 0.80 & 3.10 & 0.095 & 16.60 & 22.295 & 27.495 \\
\hline 2002 & 3.600 & 5.600 & 6.500 & 1.1 & 0.70 & 2.70 & 0.095 & 16.70 & 22.185 & 27.085 \\
\hline $3 / 2002$ & 2.950 & 5.150 & 6.050 & 1.1 & 0.70 & 2.70 & 0.095 & 16.70 & 21.535 & 26.635 \\
\hline 2003 & 2.964 & 5.164 & 6.064 & 1.1 & 0.60 & 2.45 & 0.081 & 16.80 & 21.545 & 26.495 \\
\hline 2004 & 2.964 & 5.164 & 6.064 & 1.1 & 0.60 & 2.50 & 0.080 & 16.80 & 21.544 & 26.544 \\
\hline 2005 & 2.966 & 5.166 & 6.066 & 1.2 & 0.70 & 2.80 & 0.080 & 16.80 & 21.746 & 26.946 \\
\hline 2006 & 2.958 & 5.158 & 6.058 & 1.1 & 0.75 & 2.95 & 0.080 & 16.70 & 21.588 & 26.888 \\
\hline 2007 & 2.951 & 5.151 & 6.051 & 1.1 & 0.75 & 2.95 & 0.080 & 16.64 & 21.521 & 26.821 \\
\hline 2008 & 2.771 & 4.971 & 5.871 & 1.0 & 0.70 & 2.90 & 0.080 & 16.80 & 21.351 & 26.651 \\
\hline 2009 & 2.801 & 5.001 & 5.901 & 1.0 & 0.65 & 2.70 & 0.070 & 16.80 & 21.321 & 26.471 \\
\hline $4 / 2009$ & 2.000 & 4.201 & 5.101 & 1.0 & 0.65 & 2.70 & 0.070 & 16.80 & 20.520 & 25.601 \\
\hline 2010 & 2.220 & 2.220 & 2.220 & 0.8 & 0.75 & 2.95 & 0.070 & 16.90 & 20.74 & 22.94 \\
\hline 2011 & 2.210 & 2.210 & 2.210 & 1.0 & 0.80 & 3.20 & 0.070 & 17.10 & 21.18 & 23.58 \\
\hline 2012 & 2.210 & 2.210 & 2.210 & 1.0 & 0.80 & 3.20 & 0.070 & 17.35 & 21.43 & 23.83 \\
\hline 2013 & 2.040 & 2.040 & 2.040 & 0.9 & 0.80 & 3.15 & 0.070 & 17.35 & 21.16 & 23.51 \\
\hline 2014 & 2.140 & 2.140 & 2.140 & 0.9 & 0.75 & 2.95 & 0.070 & 17.75 & 21.61 & 23.81 \\
\hline 2015 & 2.080 & 2.080 & 2.080 & 0.9 & 0.80 & 3.15 & 0.070 & 18.00 & 21.85 & 24.89 \\
\hline 2016 & 2.120 & 2.120 & 2.120 & 0.8 & 1.0 & 3.90 & 0.070 & 18.00 & 21.99 & 24.89 \\
\hline 2017 & 1.080 & 1.080 & 1.080 & 0.8 & 0.8 & 3.30 & 0.070 & 17.95 & 20.70 & 23.20 \\
\hline
\end{tabular}

This table reports the payroll tax rates by category of fund in Finland (all regions). The payroll tax cuts affected the contribution to the National health and pension insurances. The payroll tax cut resulted in these rates being brought down to zero. Hence, for example, in the first wave of the reform the rates were brought down from 2.964, 5.164 and 6.064 (depending on the firm category) to zero percent.

* Refers to firm categories by wage sums and capital depreciation.

** Category I is for wages below certain wage sums threshold, e.g. 2,059,500 euro in year 2017, and category is for wages above the threshold. The threshold varies over years.

*** Represents the average values of these insurances. 
Figure 12: Firms by industries and treatment areas

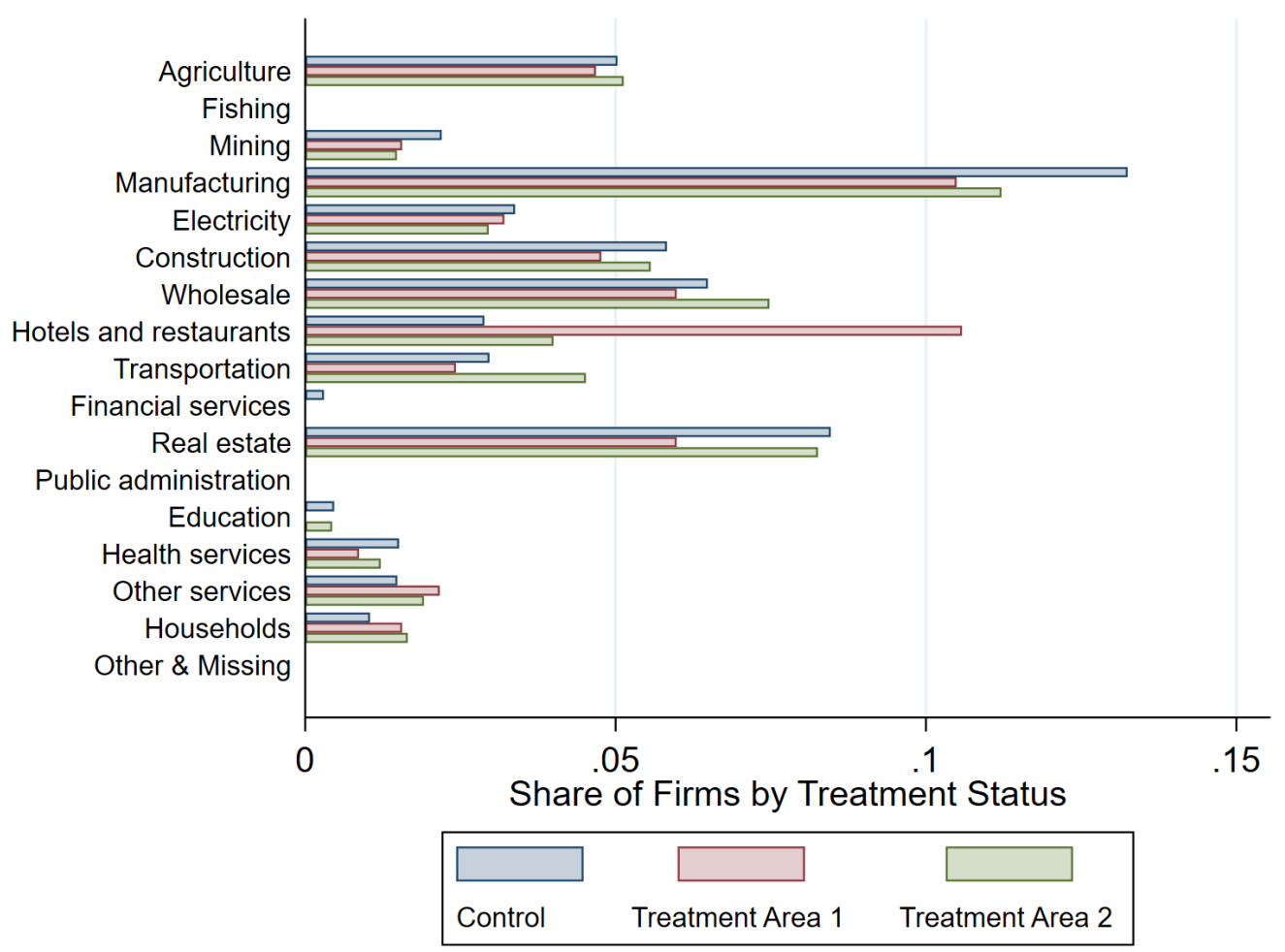

Note: This figure shows the share of firms by industry and treatment areas.

Table 9: Responses by industry categories

\begin{tabular}{|c|c|c|c|c|c|}
\hline \multirow{2}{*}{$\begin{array}{l}\text { Number of workers } \\
\text { in logs }\end{array}$} & \multicolumn{5}{|c|}{ Industry category } \\
\hline & Farming \& Mining & Manufacturing & Construction \& Transportation & Services & Finance \& Real estate \\
\hline \multirow{2}{*}{$\alpha_{2}\left(A_{i} *\right.$ Recession $\left._{t}\right)$} & -0.136 & -0.019 & 0.089 & 0.110 & -0.066 \\
\hline & $(0.094)$ & $(0.033)$ & $(0.060)$ & $(0.115)$ & $(0.056)$ \\
\hline \multirow[t]{2}{*}{$\alpha_{3}\left(A_{i} * \operatorname{Exp}_{1 t}\right)$} & 0.049 & 0.0028 & 0.031 & 0.029 & -0.102 \\
\hline & $(0.048)$ & $(0.023)$ & $(0.042)$ & $(0.044)$ & $(0.070)$ \\
\hline \multirow[t]{2}{*}{$\alpha_{4}\left(A_{i} * \operatorname{Exp}_{2 t}\right)$} & 0.061 & -0.010 & 0.001 & 0.008 & 0.044 \\
\hline & $(0.052)$ & $(0.032)$ & $(0.065)$ & $(0.086)$ & $(0.143)$ \\
\hline Observations & 6,672 & 11,876 & 12,255 & 14,359 & 6,135 \\
\hline R-squared & 0.043 & 0.067 & 0.061 & 0.085 & 0.070 \\
\hline
\end{tabular}

Note: The coefficients show the effects on firm-level outcomes in the experiment municipalities compared to the firms located in similar municipalities close by without experiencing the experiment. The coefficients are estimated using specification (1) with firm- and year-fixed effects and estimate the effects by broad industry group categories. We use data from year 1999 to year 2015 in these estimations, Exp refers to one in years 2003-2011 for the first treatment wave and 2005-2011 for the second treatment wave, Exp is two for years 2012-2015, and zero otherwise. A refers to all firms located in experiment municipalities, and zero otherwise. The standard errors in parentheses are clustered at the municipality level. 
Table 10: Exit and entry responses

\begin{tabular}{lcc}
\hline & $(1)$ & $(2)$ \\
& Exit rate & Entry rate \\
\hline$\alpha_{2}\left(A_{i} *\right.$ Recession $\left.t\right)$ & -0.008 & -0.001 \\
& $(0.011)$ & $(0.004)$ \\
\cline { 2 - 3 }$\alpha_{3}\left(A_{i} *\right.$ Exp $\left.1 t\right)$ & $-0.007^{*}$ & -0.006 \\
& $(0.004)$ & $(0.006)$ \\
$\alpha_{4}\left(A_{i} * E x p_{2 t}\right)$ & -0.006 & -0.002 \\
Control mean & $(0.004)$ & $(0.007)$ \\
Observations & 0.027 & 0.036 \\
R-squared & 1,512 & 1,512 \\
& 0.082 & 0.217
\end{tabular}

Note: The coefficients show the effects on municipality-level exit and entry rates in the experiment municipalities compared to the firms located in similar municipalities close by without experiencing the experiment. We use data from year 1999 to year 2015 in these estimations, Exp refers to one in years 2003-2011 for the first treatment wave and 2005-2011 for the second treatment wave, Exp is two for years 2012-2015, and zero otherwise. A refers to all firms located in experiment municipalities, and zero otherwise. The standard errors in parentheses are clustered at the municipality level. 
Figure 13: Number of firms exiting and entering the treatment municipalities
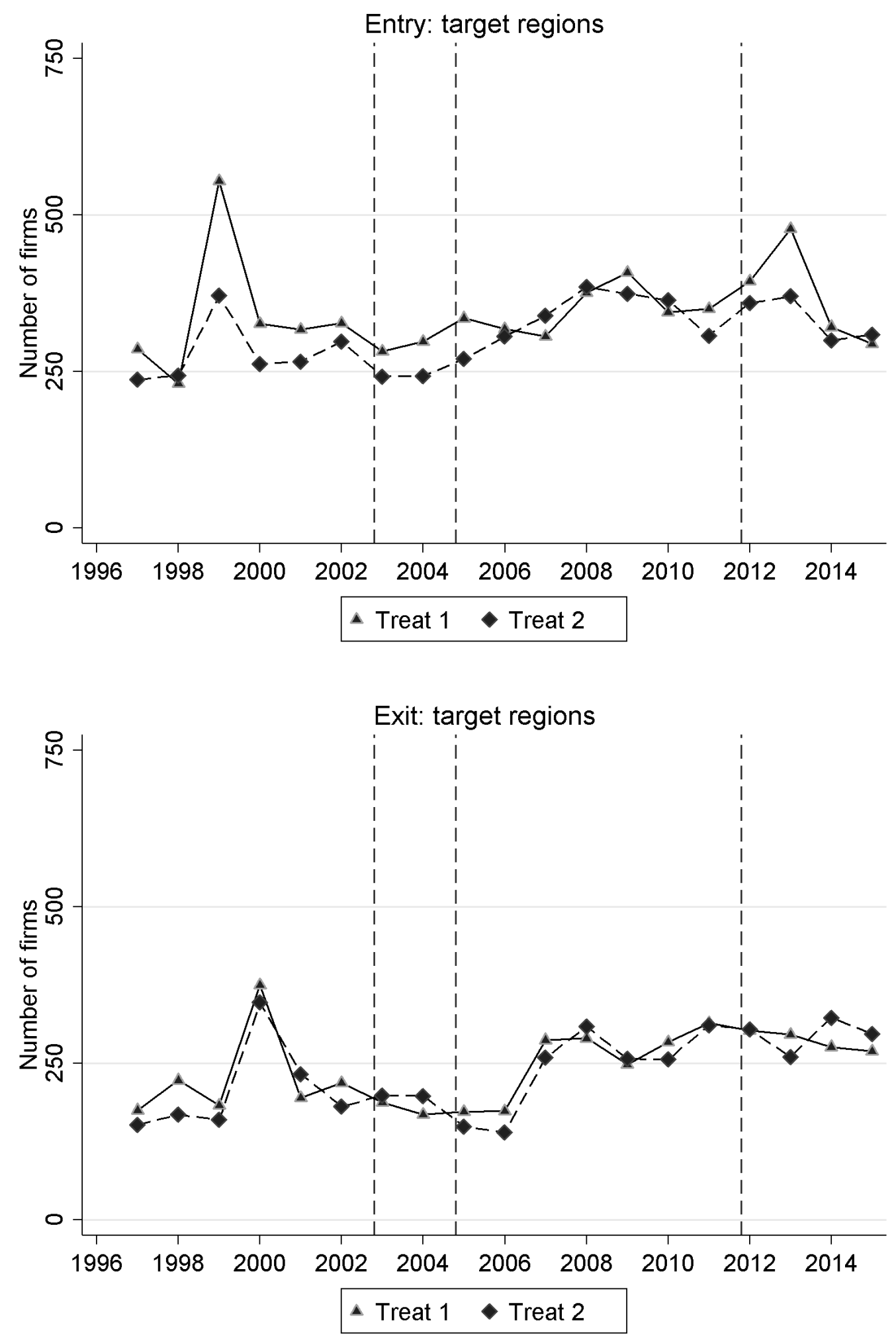

Note: These figures plot the number of new firms entering (upper panel) and exiting (lower panel) the treated municipalities by years. The first and second dashed vertical lines correspond to the start of the first and second waves of the payroll tax experiments. The thigl dashed vertical line corresponds to the end of both waves of the experiment. 
Figure 14: Number of firms moving from other municipalities to the treated municipalities
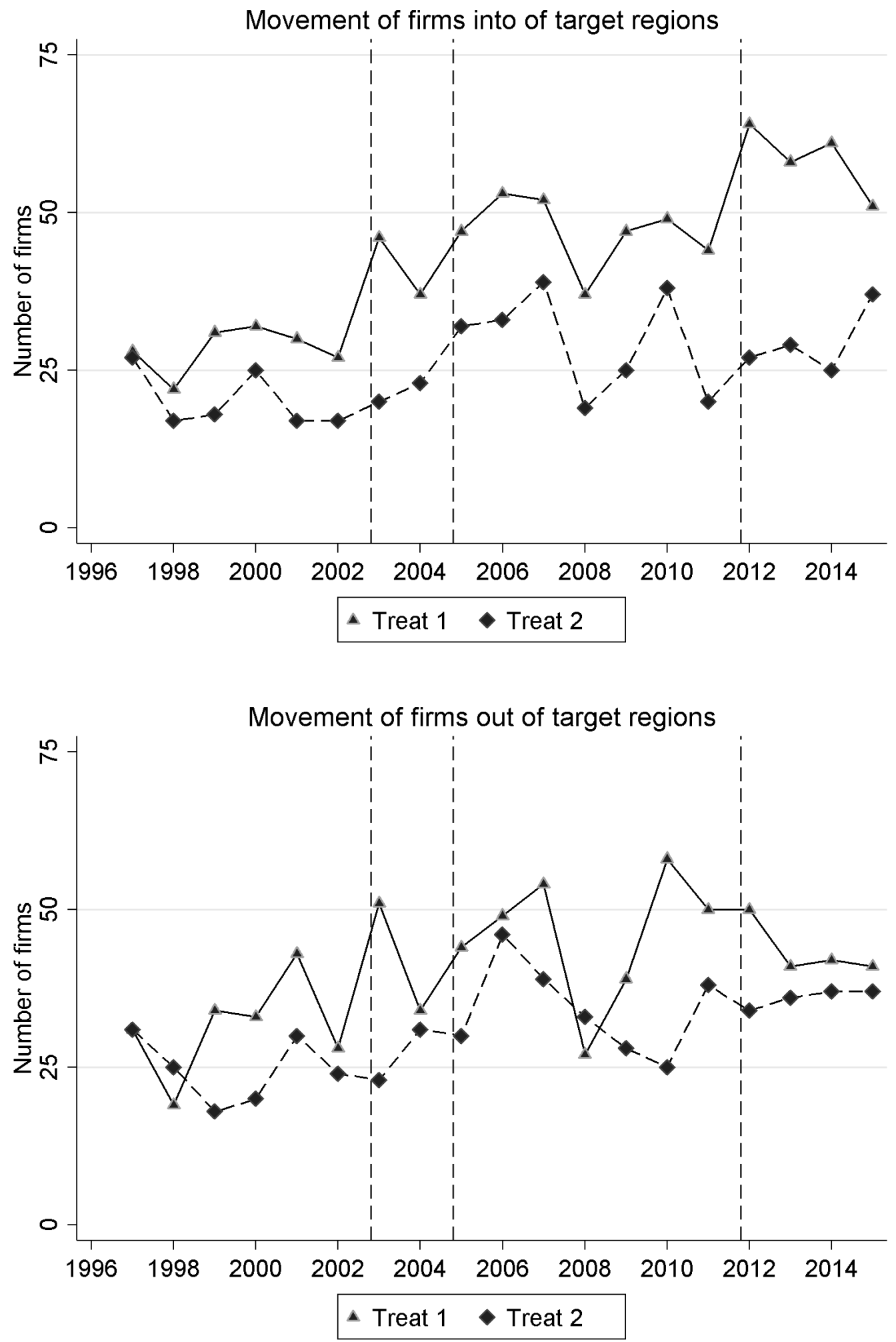

Note: These figures plot the number of existing firms moving their location into (upper panel) and out of (lower panel) the treated municipalities by years. The first and second dashed vertical lines correspond to the start of the first and second waves of the payroll tax eriments. The third dashed vertical line corresponds to the end of both waves of the experiment. 
Table 11: Firm movement in and out of the treatment municipalities

\begin{tabular}{lcc}
\hline & $(1)$ & $(2)$ \\
& Movement in rate & Movement out rate \\
\hline$\alpha_{2}\left(A_{i} *\right.$ Recession $\left._{t}\right)$ & 0.0011 & $<0.0001$ \\
& $(0.0016)$ & $(0.0001)$ \\
\cline { 2 - 3 }$\alpha_{3}\left(A_{i} *\right.$ Exp $\left._{1 t}\right)$ & -0.0008 & $<0.0001$ \\
& $(0.0012)$ & $(0.0001)$ \\
$\alpha_{4}\left(A_{i} *\right.$ Exp $\left._{2 t}\right)$ & 0.0015 & -0.0002 \\
& $(0.0023)$ & $(0.0002)$ \\
Control mean & 0.005 & 0.001 \\
Observations & 1,512 & 1,512 \\
R-squared & 0.090 & 0.071
\end{tabular}

Note: The coefficients show the effects on the share of firms moving in and out of the experiment municipalities compared to the firms located in similar municipalities close by without experiencing the experiment. We use data from year 1999 to year 2015 in these estimations, Exp refers to one in years 2003-2011 for the first treatment wave and 2005-2011 for the second treatment wave, Exp is two for years 2012-2015, and zero otherwise. A refers to all firms located in experiment municipalities, and zero otherwise. The standard errors in parentheses are clustered at the municipality level. 
Table 12: Average firm-level responses to the payroll tax experiments (without recession interactions, weighted by firm-level labor costs)

\begin{tabular}{lcccc}
\hline VARIABLES & $(1)$ & $(2)$ & $(3)$ & $(4)$ \\
in logs & $\begin{array}{c}\text { Payroll } \\
\text { taxes }\end{array}$ & $\begin{array}{c}\text { Labor costs } \\
\text { net payroll taxes }\end{array}$ & $\begin{array}{c}\text { Number of } \\
\text { workers }\end{array}$ & $\begin{array}{c}\text { Labor input } \\
\text { in months }\end{array}$ \\
\cline { 2 - 5 }$\alpha_{3}\left(A_{i} * \operatorname{Exp}_{1 t}\right)$ & $\begin{array}{c}0.286^{* * *} \\
(0.037)\end{array}$ & $0.055^{*}$ & 0.077 & 0.076 \\
$\alpha_{4}\left(A_{i} * \operatorname{Exp}_{2 t}\right)$ & -0.023 & $0.076^{*}$ & $(0.048)$ & $(0.048)$ \\
& $(0.049)$ & $(0.044)$ & $0.149^{*}$ & $0.144^{*}$ \\
Observations & 56,207 & 69,701 & $70.075)$ & $(0.075)$ \\
R-squared & 0.053 & 0.011 & 0.084 & 73,461 \\
\hline
\end{tabular}

Note: The coefficients show the effects on firm-level outcomes in the experiment municipalities compared to the firms located in similar municipalities close by without experiencing the experiment. The coefficients are estimated using specification (1) with firm-, year-, and industry-year fixed effects. We use data from year 1999 to year 2015 in these estimations, Exp refers to one in years 2003-2011 for the first treatment wave and 2005-2011 for the second treatment wave, Exp is two for years 2012-2015, and zero otherwise. A refers to all firms located in experiment municipalities, and zero otherwise. The standard errors in parentheses are clustered at the municipality level. 